\title{
Variability in spectral and nonspectral measurements of photosynthetic light utilization efficiencies
}

\author{
Oscar Schofield ${ }^{1}$, Barbara B. Prézelin ${ }^{1}$, Raymond C. Smith ${ }^{2}$, Petra M. Stegmann ${ }^{3}$, \\ Norman B. Nelson ${ }^{1}$, Marlon R. Lewis ${ }^{3}$, Karen S. Baker ${ }^{4}$ \\ ${ }^{1}$ Department of Biological Sciences and Marine Science Institute, University of California, Santa Barbara, California 93106, \\ USA \\ ${ }^{2} \mathrm{CSL} / \mathrm{Center}$ for Remote Sensing and Environmental Optics, UCMBO and Geography Department, University of California, \\ Santa Barbara, California 93106, USA \\ ${ }^{3}$ Department of Oceanography, Dalhousie University, Halifax, Nova Scotia, Canada B3H 4J1 \\ ${ }^{4}$ University of California Marine Bio-optics, Scripps Institution of Oceanography, UCSD, La Jolla, California 92093, USA
}

\begin{abstract}
The aim of this study was to quantify the variability in and differences between spectral and nonspectral measurements of light utilization efficiencies for natural phytoplankton communities, in order to evaluate possible consequences for bio-optical models of in situ primary production $(P)$ Field samples were collected at 4 coastal stations during a $1 \mathrm{~d}$ transect (July 23, 1988) across the Southern California Counter (urrent (SCCC) at a time when phytoplankton communities were dominated largely by picoplankton $(0.4$ to $5 \mu \mathrm{m})$. Concurrent determinations were made of downwelling spectral irradiance $\left[Q_{d}(\lambda, z)\right]$, photosynthetically available radiation $\left(Q_{p a r}\right)$, spectral attenuation coefficients $\left[K_{d}(\lambda, z)\right]$, detrital-corrected phytoplankton absorption $\left[a_{\mathrm{ph}}(\lambda, z)\right]$, white light photosynthesis-irradiance parameters $\left(P_{\operatorname{mlx}}, \alpha, I_{k}\right)$ and carbon action spectra $\alpha\left(\Delta \lambda_{i}, z\right)$. From these parameters, spectral estimates of in situ phytoplankton absorbed radiation $\left[A Q_{\mathrm{p} h}\left(\Delta \lambda_{1}, z\right)\right]$, maximum quantum yield $\left[\phi_{\max }\left(\Delta \lambda_{k} z\right)\right]$, operational quantum yield $\left[\phi\left(\Delta \lambda_{1}, z\right)\right]$, radiation utilization efficiency $\left[\epsilon\left(\Delta \lambda_{n}, z\right)\right]$ and productivity $P\left(\Delta \lambda_{n} z\right)$ were derived. Significant spatial variability in all bio-optical parameters was noted for communities in the surface waters and the chlorophyll maximum. For surface waters, there was significant variability in the 525 to $600 \mathrm{~nm}$ region of the spectral signatures of $\phi\left(\Delta \lambda_{1}, z\right)$ and $P\left(\Delta \lambda_{1}, z\right)$ which was attributable to phycobilins not resolved in absorption spectra. The importance of light absorption by photosynthetic pigments other than chlorophyll a (chl), and their associated impact upon absorption-based production parameters, increased with light depth. One consequence was a close correspondence between $A Q_{\mathrm{ph}}$ and $P\left(\Delta \lambda_{i} z\right)$ at depth which was not evident in surface waters. A second consequence was that while spectrally weighted and white light estimates of quantum yield were occasionally similar in surface waters, spectral estimates for all chlorophyll maximum communities were 4 - to 6 -fold higher than white light measurements. Results confirm previous observations that white light measures of quantum yield can significantly underestimate quantum yield for subsurface communities of phytoplankton (Prézelin et al. 1989) and provide a conceptual base on which to improve existing and future spectral models of in situ photosynthetic quantum yield.
\end{abstract}

\section{INTRODUCTION}

Phytoplankton productivity occupies a central position in several large-scale processes, including food web dynamics, biogeochemical cycles, particle flux, and bioluminescence. Bio-optical models can increase our ability to resolve the temporal/spatial variability in phytoplankton production which will allow constraints to be placed on these other processes. The bio-optical models are based on the mechanistic linkages between water-column optical properties, penetration of photosynthetically available radiation $\left(Q_{\mathrm{par}}\right)$, and phytoplankton production. Photosynthesis-irradiance (P-I) curves provide physiological information which can resolve environmental effects on algal photophysiology and are used to provide empirical models describ- 
ing the variability in primary production (Platt \& Jassby 1976, MacCaull \& Platt 1977, Cote \& Platt 1984, Prézelin et al. 1986, 1987, 1989, 1991, Prézelin \& Glover 1991). The P-I parameters are also key cornponents in other sophisticated bio-optical models which attempt to predict changes in the rates of phytoplankton growth and photosynthesis (Shuter 1979, Laws \& Bannister 1980, Kiefer \& Mitchell 1983, Falkowski et al. 1985, Lewis et al. 1985, Geider et al. 1986, Bidigare et al. 1987, Platt \& Sathyendranath 1988, Sakshaug et al. 1989, 1991, Sathyendranath et al. 1989, Smith et al. 1989b, Baker et al. 1990). These models generally require a term for the quantum yield of carbon fixation $(\phi)$ which is the efficiency with which radiation absorbed by phytoplankton $\left(A Q_{\mathrm{ph}}\right)$ is converted to photosynthate. Based on limited field information on the quantum yield many of these models have been developed by assuming $\phi$ is independent of wavelength, near the theoretical maximum $\left(0.125 \mathrm{~mol} C\right.$ Ein $\left.^{-1}\right)$ and/or has a predictable light-dependent relationship to the maximum quantum yield $\left(\phi_{\max }\right)$. Recent studies indicate that such generalities cannot be universally applied without significantly affecting the predictive accuracy of the productivity models (Smith et al. 1989b. Schofield et al. 1990)

Spectral production models (Lewis et al. 1985, Bidigare et al. 1987, Sathyendranath et al. 1987, Smith et al. 1989b, Baker et al. 1990) recognize the wavelength dependence of photosynthesis and that the bio-optical properties of phytoplankton are adaptable to the variability in the underwater light fields (cf. Prézelin \& Boczar 1986). The models are based on the observation (Kirk 1983) that primary production $(P)$ at any given depth $(z)$ depends on the underwater light field, its absorption by phytoplankton, and the efficiency with which this absorbed radiation $\left(A Q_{p h}\right)$ is utilized to fix carbon (C). Thus

$$
P(z)=\phi(z) \cdot 12000 \cdot A Q_{p h}(z)
$$

Taking into account the spectral dependence of $A Q_{\mathrm{ph}}(z)$ the accuracy of the bio-optical models significantly increased (Smith et al. 1989b). By also taking into account the spectral dependence in $\phi(z)$ the accuracy of the productivity models will increase and may offer more general applications then empirical and nonspectral models

Our interests in modeling the mechanisms with which diverse phytoplankton utilize radiant energy, regulate rates of photosynthesis, and influence the optical characteristics of the water column prompted a multidisciplinary cruise (Watercolors '88). The purpose of Watercolors ' 88 was to assess the linkages between ocean optics and wavelength-dependent photosynthesis. The study presented here is part of that field exercise and was designed to quantify natural variabil- ity in and between spectral and nonspectral measurements of the maximum quantum yield. The study outlines the linkages between spectral and nonspectral production parameters, demonstrates that shifts in phytoplankton community composition and/or spectral irradiance has a large effect on the spectral signature of light utilization parameters, confirms previous observations that 'white light' measures of quantum yield can significantly underestimate quantum yield for subsurface communities of phytoplankton (Prézelin et al. 1989) and provides a conceptual base on which to improve existing and future spectral models of in situ photosynthetic quantum yield.

\section{MATERIALS AND METHODS}

Physical/chemical measurements and sample collection. The Watercolors ' 88 program was conducted in July-August 1988 aboard the RV 'Melville'. Using procedures previously described (Smith et al 1987), a total of 129 vertical profiles of bio-optical properties were completed during repeated transects of a highly variable region of the Southern California Bight (SCB) (Fig. 1). Hydrographic analyses (Smith et al. 1990, Baker \& Smith pers. comm.) led to the sorting of all vertical profiles into 12 groupings which had similar hydrographic signatures. The cluster of vertical casts that represent Station (Stn) L was most representative of California Current (CC) waters flowing from the north, while the stations at Stn $\mathrm{K}$ had hydrographic signatures that were intermediate between those $C C$ waters and post-upwelling water subducting offshore at Stn J. Although groups A to I all appeared hydrographically related to the Southern California Counter Current ( $\mathrm{SCCC}$ ), there was some variability along the east-west transect line. The variability was most pronounced at Stn I centered over the Continental Shelf Break. At the time of the present study, Stn 12.01 showed the influence of SCCC in surface waters and the influence of postupwelling off Pt. Conception within the chlorophyll maximum (chl max).

On July 23, 1988, a bıological transect was made along a $150 \mathrm{~km}$ region of the SCCC. The cast numbers for the 4 transect stations (Stns 9.02, 10.02, 11.01, $\& 12.01)$ and their relationship to distinguishable water types (A to L) are shown in Fig 1. Vertical profiling for Stns 9.02 to 12.01 was carried out between dawn and dusk of a single day and sample times are listed in Table 1 The present study distinguishes instantaneous measurements of bio-optical parameters, made at different stations at different times of day, from noon-time estimates of these parameters. The latter correct for known diurnal variations in light and productivity parameters in order to provide a time-independent compari- 
Fig. 1 Site of 12 transect locations (A to $\mathrm{L}$ ) that were repeatedly sampled during the Watercolors cruise during $4 \mathrm{wk}$ in July and August 1988. (ロ) Stations where biooptical profiles were made between dawn (Stn 9.02) and dusk (Str 12.01) on July 23 (Julian Day 205). Specific cast card numbers for BOPS data presented here are indicated

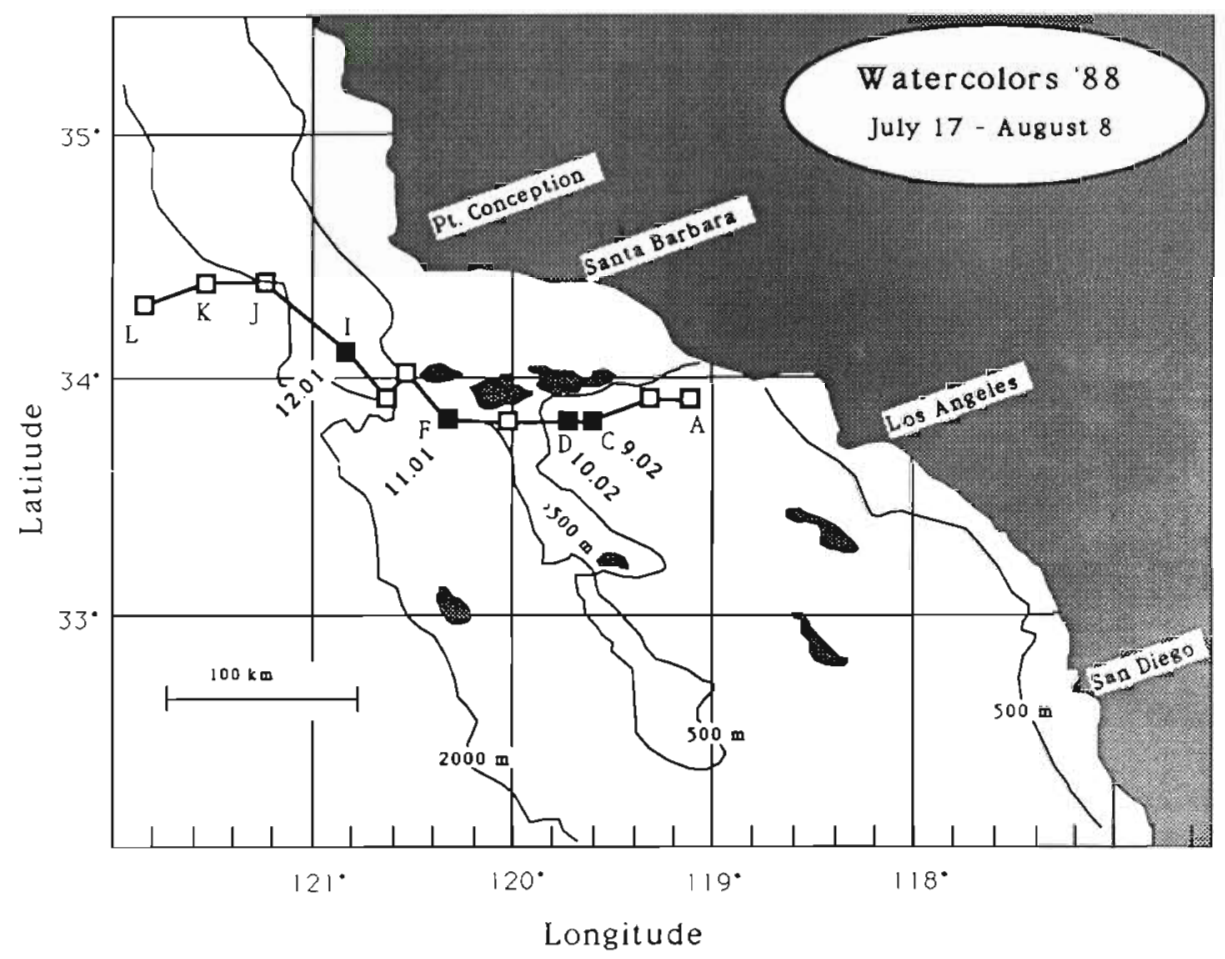

The Bio-Optical Profiling System (BOPS) was used to determine the vertical structure of the water column and to collect seawater samples for chemical son of the 4 stations. Procedures for time-correction of similar bio-optical parameters are described elsewhere (Prézelin et al. 1987, 1989, Prézelin \& Glover 1991)

Table 1. Physical, chemical and production values across an east-west transect of the Southern California Bight on July $23,1988$. See Table 2 for definition of symbols. nd: not detectable, $<1 \mu \mathrm{M}$

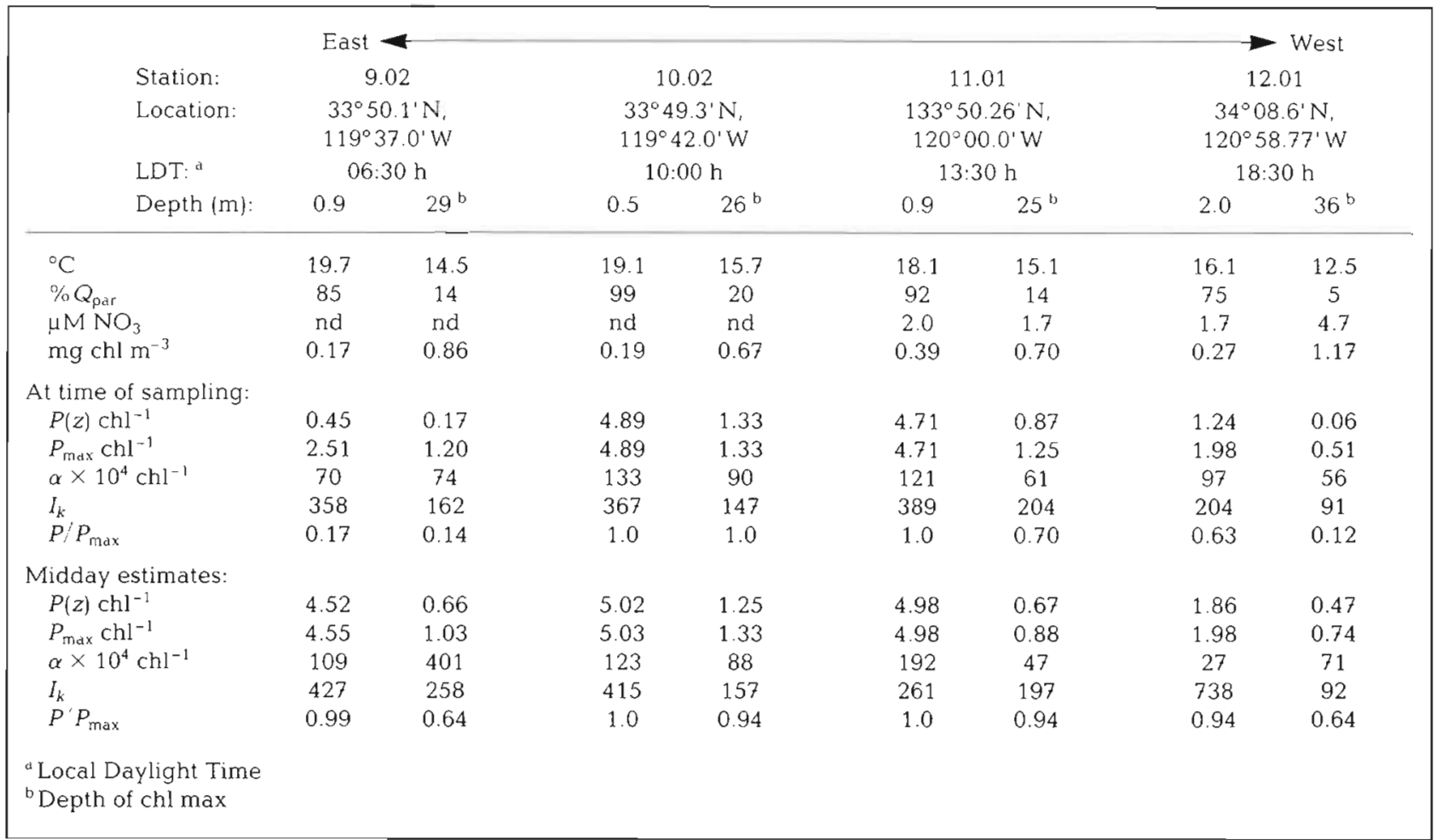


Table 2. Symbols used in this paper

\begin{tabular}{|c|c|c|c|}
\hline \multirow[t]{2}{*}{$A Q_{p+2}(Z)$} & \multirow{2}{*}{$\begin{array}{l}\text { Quanta absorbed by phytoplankton } \\
\text { between } 400 \text { and } 700 \mathrm{~nm} \text { at depth } z \text {, } \\
\text { Ein } \mathrm{m}^{-3} \mathrm{~h}^{1}\end{array}$} & $z$ & Depth in meters \\
\hline & & $\alpha \operatorname{chl}^{-1}$ & $\begin{array}{l}\text { Chl-specific intial slope of P-I curve, } \\
m g C(m g \text { chl })^{-1} h^{-1}\left(\mu \text { Ein } m^{-2} s^{-1}\right)^{-1}\end{array}$ \\
\hline$A Q_{\mathrm{p}: i}\left(\Delta \lambda_{1}, z\right)$ & $\begin{array}{l}\text { Quanta absorbed by phytoplankton } \\
\text { between } \lambda_{1} \text { and } \lambda_{2} \text { at depth } z \text {, Ein } \mathrm{m}^{-3} \\
\mathrm{~h}^{-1}\end{array}$ & $\alpha\left(\Delta \lambda_{1}, z\right) c h l^{-1}$ & $\begin{array}{l}\text { Wavelength-dependent chl-specific } \\
\text { efficiency of light-limited photo- } \\
\text { synthesis, mg C (mg chl })^{-1} \mathrm{~h}^{-1}\end{array}$ \\
\hline \multirow[t]{2}{*}{$a_{\mathrm{ph}}(\lambda, z) \mathrm{chl}^{-1}$} & \multirow{2}{*}{$\begin{array}{l}\text { Chl-specific spectral absorption of } \\
\text { phytoplankton at depth } z, \mathrm{~m}^{2} \\
\text { (mg chl })^{-1}\end{array}$} & & $\left(\mu \operatorname{Ein} \mathrm{m}^{-2} \mathrm{~s}^{-1}\right)^{-1}$ \\
\hline & & $\bar{\alpha}\left(\Delta \lambda_{1}, z\right) \mathrm{chl}^{-1}$ & $\begin{array}{l}\text { Spectrally averaged chl-specific } \\
\text { wavelength-dependent efficiency of }\end{array}$ \\
\hline$\overline{a_{p h}} \mathrm{chl} l^{-1}$ & $\begin{array}{l}\text { Spectrally weighted chl-specific ab- } \\
\text { sorption, } \mathrm{m}^{2}(\mathrm{mg} \mathrm{chl})^{-1}\end{array}$ & & $\begin{array}{l}\text { light-limited photosynthesis, mg C } \\
\text { (mg chl })^{-1} \mathrm{~h}^{-1}\left(\mu \text { Ein } \mathrm{m}^{-2} \mathrm{~s}^{-1}\right)^{-1}\end{array}$ \\
\hline chl & $\begin{array}{l}\text { Chlorophyll a concentration, mg chl } \\
\mathrm{m}^{-3}\end{array}$ & $\overline{\alpha_{(P-1)}} \mathrm{chl}^{-1}$ & $\begin{array}{l}\text { Chl-specific light-limited slope of } \\
\text { photosynthesis weighted to the irra- }\end{array}$ \\
\hline$E_{d}(\lambda, z)$ & $\begin{array}{l}\text { Spectral downwelling irradiance } \\
(10 \mathrm{~nm} \text { bandwidth }) \text { at depth } z, \mathrm{~W} \mathrm{~m}^{-2} \\
\mathrm{~nm}^{-1}\end{array}$ & & $\begin{array}{l}\text { diance within a white light photo- } \\
\text { synthetron, mg C (mg chl) })^{-1} \mathrm{~h}^{-1} \\
\left(\mu \text { Ein } \mathrm{m}^{-2} \mathrm{~s}^{-1}\right)^{-1}\end{array}$ \\
\hline \multirow[t]{2}{*}{$I_{k}$} & \multirow{2}{*}{$\begin{array}{l}\text { Saturation parameter for photo- } \\
\text { synthesis-irradiance (P-I) curves, = } \\
P \quad a, \mu \text { Ein } m^{-2} s^{-1}\end{array}$} & $\lambda$ & Wavelength, nm \\
\hline & & $\Delta \lambda_{1}$ & Integrated value of a parameter be- \\
\hline$P(z) \mathrm{chl}^{-1}$ & $\begin{array}{l}\text { Rate of chl-specific photosynthesis, } \\
m g C(m g c h l)^{-1} \mathrm{~h}^{-1}\end{array}$ & & $\begin{array}{l}\text { Ween } \lambda_{1} \text { and } \lambda_{2} \text { corresponding to a } \\
\text { waveband interval } i\end{array}$ \\
\hline \multirow[t]{2}{*}{$P(\Delta \lambda, z) \mathrm{chl}^{-1}$} & \multirow{2}{*}{$\begin{array}{l}\text { Chl-specific photosynthetic action } \\
\text { spectrum at depth } z, \mathrm{mg} C(\mathrm{mg} \text { chl })^{-1} \\
\mathrm{~h}^{-1}\end{array}$} & $\epsilon(\Delta \lambda, z)$ & $\begin{array}{l}\text { Wavelength-dependent radiation } \\
\text { utilization efficiency at depth } z\end{array}$ \\
\hline & & $\phi\left(\Delta \lambda_{1 i} z\right)$ & Wavelength-dependent quantum \\
\hline$p_{\max } c_{h l}{ }^{-1}$ & $\begin{array}{l}\text { Light-saturated chl-specific rate of } \\
\text { photosynthesis, mg } \mathrm{C} \text { (mg chl })^{-1} \mathrm{~h}^{-1}\end{array}$ & & $\begin{array}{l}\text { yield for carbon fixation at depth } z \text {, } \\
\text { mol C } \text { Ein }^{-1}\end{array}$ \\
\hline$K_{d}(\lambda, z)$ & $\begin{array}{l}\text { Spectral attenuation coefficients at } \\
\text { depth } z, \mathrm{~m}^{-1}\end{array}$ & $\bar{\phi}\left(\Delta \lambda_{1}, z\right)$ & $\begin{array}{l}\text { Spectrally averaged wavelength- } \\
\text { dependent quantum yield for carbon }\end{array}$ \\
\hline \multirow[t]{2}{*}{$Q_{d}\left(\Delta \lambda_{1}, z\right)$} & \multirow{2}{*}{$\begin{array}{l}\text { Spectral quantum irradiance at } \\
\text { depth } z, \mu E_{i n} \mathrm{~m}^{-2} \mathrm{~s}^{-1} \mathrm{~nm}^{-1}\end{array}$} & & fixation at depth $z_{1}$ mol C Ein $^{-1}$ \\
\hline & & $\phi_{\max }(z)$ & Maximum quantum yield for carbon \\
\hline$Q_{d}\left(\Delta \lambda_{n} \mathrm{P}-\mathrm{I}\right)$ & $\begin{array}{l}\text { Spectral quantum irradiance in } \\
\text { white light photosynthetron, } \mu \text { Ein } \\
m^{-2} s^{-1} n^{-1}\end{array}$ & & $\begin{array}{l}\text { fixation measured with a white light } \\
\text { photosynthetron at depth } z \text {, mol C } \\
\text { Ein }^{-1}\end{array}$ \\
\hline \multirow[t]{2}{*}{$Q_{\text {par }}$} & \multirow{3}{*}{$\begin{array}{l}\text { Photosynthetically active quantum } \\
\text { irradiance between } 400 \text { and } 700 \mathrm{~nm} \\
\text { at depth } z, \mu E \text { Ein } \mathrm{m}^{-2} \mathrm{~s}^{-1} \mathrm{~nm}^{-1} \text { (Note: } \\
Q_{\text {par }}=P A R=I=\mathrm{E} \text { ) } \\
\text { Photosynthetically active quantum } \\
\text { irradiance in white photosynthetron, } \\
\mu \text { Ein } \mathrm{m}^{-2} \mathrm{~s}^{1} \mathrm{~nm}^{-1}\end{array}$} & $\phi_{\max }\left(\Delta \lambda_{1}, z\right)$ & $\begin{array}{l}\text { Wavelength-dependent maximum } \\
\text { quantum yield for carbon fixation at } \\
\text { depth } z, \mathrm{~mol} \mathrm{C} \mathrm{Ein}{ }^{-1}\end{array}$ \\
\hline & & $\overline{\phi_{\max }}(\Delta \lambda, z)$ & Spectrally averaged wavelength- \\
\hline$Q_{\text {par(P-I) }}$ & & & $\begin{array}{l}\text { dependent maximum quantum yield } \\
\text { for carbon fixation at depth } z_{\text {, }} \\
\text { mol C Ein'- }\end{array}$ \\
\hline
\end{tabular}

and biological analysis at each station (Smith et al. 1984). Hydrographic features (i.e. density structure, chl and particle distributions, in situ light fields, etc.) were identified during the downcast and confirmed on the upcast, at which time water samples were collected from discrete depths in $5 \mathrm{l}$ GoFlo botthes for shipboard studies. Methods for chlorophyll a (chl) and nitrate determinations of discrete samples were identical to those described by Smith et al. (1987).

Bio-optical parameters. Significant symbols used in the present text to describe measured anc derived optical and productivity parameters are summarized in Table 2. Some symbols are interchangeable and reflect overlapping biological and optical notation. A flow chart of the linkages between measured and derived optical parameters is given in Fig 2.

$E_{d}(\lambda, z), K_{d}(\lambda, z)$ and $Q_{d}\left(\Delta \lambda_{i} z\right)$ : Vertical profiles of downwelling spectral irradiance $E_{d}(\lambda, z)\left(\mathrm{W} \mathrm{m}^{-2} \mathrm{~nm}^{-1}\right)$ were corrected for variability in the incident light field over the day resulting from atmospheric variability, wave action, and ship shadow (Smith \& Baker 1984). Spectral attenuation coefficients $\left[K_{d}(\lambda, z)\right]$ were calculated from spectral irradiance measurements $(10 \mathrm{~nm}$ bandwidths):

$$
K_{d}(\lambda, z)=\frac{-1}{\left(z_{1}-z_{2}\right)} \cdot \ln \frac{E_{d}\left(\lambda, z_{1}\right)}{E_{d}\left(\lambda, z_{2}\right)}
$$

Spectral quantum irradiance, $Q_{d}(\lambda)\left(\mu\right.$ Ein $\mathrm{m}^{-2} \mathrm{~s}^{-1}$ $\mathrm{nm}^{-1}$ ), was calculated from $E_{d}(\lambda)$ as outlined in Smith et 


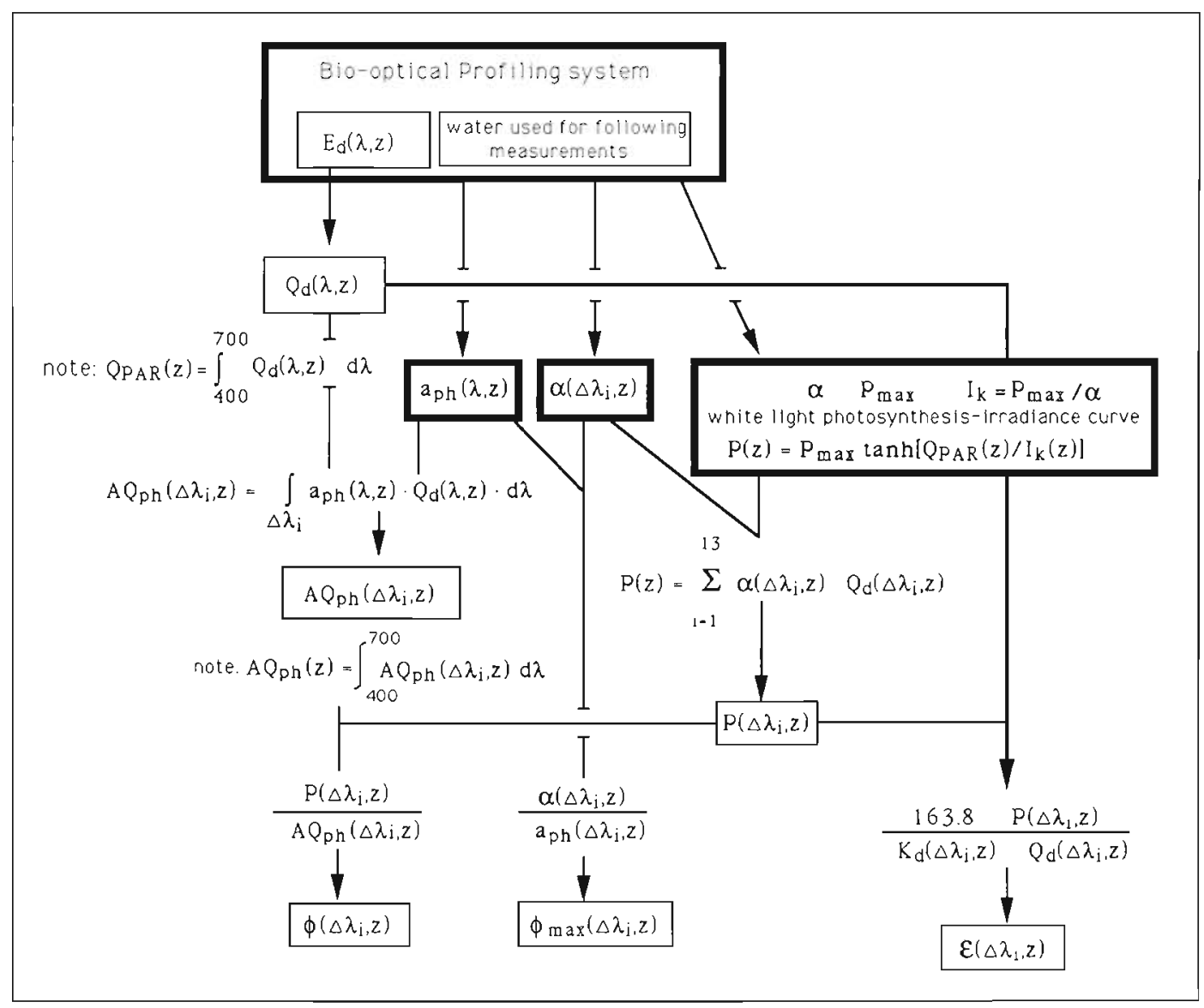

Fig. 2. Flow chart of measured and derived optical parameters. See text for details

al. (1989a). The resulting spectral signature of $Q_{d}(\lambda)$ was then averaged over $25 \mathrm{~nm}$ wavebands to give $Q_{d}\left(\Delta \lambda_{i}\right)$ where $\Delta \lambda_{i}$ refers to parameter values determined over a $25 \mathrm{~nm}$ waveband corresponding to spectral photosynthetron wavebands (see below).

Detrital-corrected $a_{p h}(\lambda, z), A Q_{p h}\left(\Delta \lambda_{i r} z\right)$, and $A Q_{p h}(z)$ : Phytoplankton spectral absorption $\left[a_{\mathrm{ph}}(\lambda, z)\right]$ was determined using the opal glass technique on whole water samples that had been gently filtered $(<10 \mathrm{~mm} \mathrm{Hg}$. $0.4 \mu \mathrm{m}$ Nuclepore polyester filters), and resuspended by gentle agitation ( $30 \mathrm{~s}$, Thermolyne 37600 shaker) of the filter in $10 \mathrm{ml}$ of the seawater filtrate. Absorption spectra of the resuspended particles were measured using an Aminco DW-2a spectrophotometer with sample filtrate as the blank (Nelson \& Prézelin 1990). Replicate absorption measurements were made on serially diluted samples in order to confirm that Beer's law applied and optical densities were $<0.05$ (> 89\% transmittance) to ensure that multiple scattering effects were insignificant (Kirk 1983, Morel et al. 1987, Sathyendranath et al. 1987).

Once absorption spectra were recorded, suspensions were refiltered and extracted chl concentrations determined. High Pressure Liquid Chromatography (HPLC) analyses of selected filters showed no systematic bias toward retention of particular pigments on the filter (R. R. Bidigare pers. comm.). Refiltered extracts were compared to chl concentrations of whole water suspensions, in order to correct for pigment loss $(<36 \%$ on the average) and to allow for direct estimates of in situ absorption parameters. Chl concentrations of refiltered particle suspensions were used to determine chl-specific absorption parameters.

Direct measurements of total particle absorption were 'detrital'-corrected following the procedure of Kishino et al. (1985). Aliquots of particle suspensions were extracted overnight in cold methanol and filtered to collect pigment extracted particles. These particles were resuspended in distilled water and their spectral absorption determined, thereby providing 'detrital' spectra which were subtracted from total particle absorption to yield detrital-corrected spectral absorption of phytoplankton $\left[a_{\mathrm{ph}}(\lambda)\right]$. All spectra were smoothed by a $5 \mathrm{~nm}$ moving average.

A spectral estimate of the amount of available radiation absorbed by phytoplankton was calculated as a 
product of the phytoplankton absorption $\left(a_{\mathrm{ph}}(\lambda . z) ; \mathrm{m}^{-1}\right)$ and the in situ spectral irradiance at the sampling depth $\left[Q_{d}(\lambda . z)\right.$; Ein $\mathrm{m}^{-2} \mathrm{~h}^{-1} \mathrm{~nm}^{-1}$ I (Smith et al. 1989b). The resulting estimate of phytoplankton absorbed radiation $\left(A Q_{p h}(\lambda .2)\right.$; Ein $\left.m^{-3} h^{-1}\right)$ is an upper limit as no corrections were made for the fraction of absorbed light attributable to nonphotosynthetic pigments (Prézelin et al. 1990). Estimates of $A Q_{p h}(\lambda . z)$ were integrated over 13 separate $25 \mathrm{~nm}$ waveband intervals to yield spectrally absorbed radiation [i.e. $A Q_{\mathrm{ph}}\left(\Delta \lambda_{i} . z\right)$; Ein $\mathrm{m}^{-3} \mathrm{~h}^{-1}$ ] for each waveband interval used to measure rates of photosynthesis in spectral photosynthetrons (see below), i.e.

$$
A Q_{\mathrm{ph}}(\Delta \lambda i, z)=\int_{\Delta \lambda_{i}} Q_{d}(\lambda, z) \cdot a_{\mathrm{ph}}(\lambda, z) \cdot d \lambda
$$

Summing $A Q_{\mathrm{ph}}\left(\Delta \lambda_{1}, z\right)$ over the visible spectrum (i.e. $i=1$ to 13) yields an estimate of the total absorbed radiation by phytoplankton $\left[A Q_{\mathrm{ph}}(z)\right]$.

$\boldsymbol{P}_{\max }, \boldsymbol{\alpha}$, and $\boldsymbol{I}_{k}$ : Short-term (2 h) shipboard ${ }^{14} \mathrm{C}$-incubations of whole water samples were made to determine 'instantaneous' photosynthesis-irradiance (P-I) relationships of $\geq 0.4 \mu \mathrm{m}$ phytoplankton communities. Samples were incubated at in situ temperature and over a range of white light intensities. The procedures of sample collection, preparation, incubation and radiolabel uptake determinations have been described previously (Prézelin et al. 1989). Non-linear curve fits for P-I data were calculated using the simplex method of Caceci \& Cacheris (1984). Curve-fitting procedures provided estimates of $P_{\max }$ (the light-saturated rate of photosynthesis), $\alpha$ (the light-limited rate of photosynthesis) and $I_{k}\left(=P_{\max } \alpha\right.$, an estimate of the minimum irradiance required to light-saturate rates of photosynthesis). In situ photosynthetic performance $P(z)$ was calculated as

$$
P(z)=P_{\max }(z) \cdot \tanh \left[Q_{\text {par }}(z) I_{k}(z)\right]
$$

where $Q_{\text {par }}(z)$ is the in situ irradiance (Platt \& Gallegos 1980).

During the cruise, each of these P-I parameters, spectral irradiance, and phytoplankton absorption were determined diurnally for phytoplankton communities sampled from similar depths and hydrographic regimes and from large-volume deckboard incubators adjusted to in situ light and temperature levels (cf. Prézelin et al. 1987). Thus diurnal variability in P-I parameters was determined for different groups of hydrographically similar transect stations. This diurnal pattern was replicated during a second diurnal study within SCCC waters during the cruise. Within hydrographic groupings, it was then possible to anchor an instantaneous measurement of a production parameter made at other times during the cruise to a characteristic diurnal pattern. The instantaneous measure- ment set the magnitude of the anchor point for that day and location, while the diurnal pattern of periodicity was used to propagate a pattern of daily variation most likely to be operating within that hydrographic group. This approach had been successfully employed in a previous effort to monitor and model temporal and spatial variability in primary production across this same region of the ocean in 1985 and shown to provide a reasonable estimation of hourly variation in $P(z)$ over the day and as a function of light depth at different transect stations (Prézelin et al. 1987, Smith et al. 1987. $1989 b)$

$\alpha\left(\Delta \lambda_{i}, z\right)$ and $P\left(\Delta \lambda_{i}, z\right)$ : Two types of spectral photosynthetrons and procedures were used to determine the carbon action spectra (C-action) of phytoplankton (Lewis et al. 1985, Schofield et al. 1990). The major procedural difference was that the Lewis spectral photosynthetron system was designed to give the spectral light-limited slope of photosynthesis $\left\{\alpha\left(\Delta \lambda_{j}, Z\right)\right\}$ for whole water samples, while the Prézelin system was designed to allow for determinations of either whole water or size-fractionated samples of larger volumes (up to $15 \mathrm{ml}$ ). Further, the Prézelin system provided the option for measuring enhanced photosynthetic $C$ action spectra (Fig. 3).

The Prézelin system provided $\alpha\left(\Delta \lambda_{j i} z\right)$ and spectral production measurements for $>0.4 \mu \mathrm{m}$ phytoplankton in surface water. The Lewis system was used to measure $\alpha\left(\Delta \lambda_{1} z\right)$ and production values for whole water

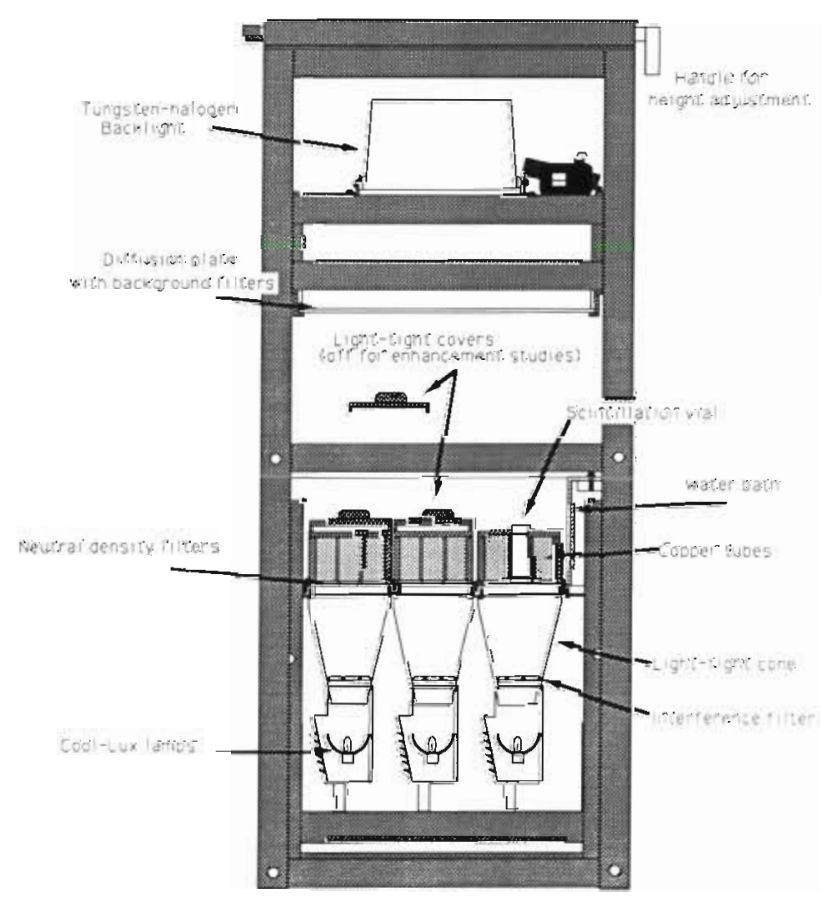

Fig. 3. Diagram of large volume spectral photosynthetron with enhancement attachment. See text for details 
samples of chl max communities along the transect. A control study of chl max samples at Stn C showed good replication of results between the 2 spectral photosynthetrons. Therefore, it appeared that fractional contribution of $<0.4 \mu \mathrm{m}$ phytoplankton to total plant biomass was insignificant in the SCCC at the time of this study

Surface samples were inoculated with $\mathrm{NaH}^{14} \mathrm{CO}_{3}$ (final activity ca $5 \mu \mathrm{Ci} \mathrm{ml} \mathrm{m}^{-1}$ ) and $2 \mathrm{ml}$ aliquots were dispensed into acid-washed scintillation vials and incubated ( 2 h) at in situ temperatures. Described here for the first time, the Prézelin spectral photosynthetron irradiated samples with a range of spectral irradiances provided by an array of $75 \mathrm{~W}$ Cool Lux FOS8 tungsten halogen lamps. These lamps were individually centered in a light-tight fitting beneath a $2 "(5 \mathrm{~cm})$ square glass bandpass interference filter (PTR Optics, Waltham, MA, USA, and Corion Optics, Hollingston, MA, USA). There were 13 different spectral filters, each with $12.5 \mathrm{~nm}$ half-bandwidth, which were equally spaced across the visible spectrum (with the halfbandwidths centered from 400 to $700 \mathrm{~nm}$ ) in $25 \mathrm{~nm}$ increments. Above each filter, a water-cooled Plexiglas chamber was aligned with a light-tight reflecting cone. Within each chamber was a sample holder comprised of 5 copper tubes with an inner diameter equivalent to the outer diameter of $20 \mathrm{ml}$ glass incubation vials. The spectral integrity of the light reaching each sample location was verified with the aid of a Li-Cor LI-1800 spectroradiometer. Irradiance levels within each sample could be modified by using various combinations of neutral density Plexiglas discs between the glass vials and the base of the incubation chamber. Irradiance was measured with a Li-Cor LI-185A light meter and an attached underwater quantum sensor which fitted into each sample chamber so that light measurements were made at the chamber base without light leaks from above. Drift in mean irradiance measurements during incubation was less than $5 \%$. Following incubation, samples were filtered onto $0.4 \mu \mathrm{m}$ Nuclepore filters, rinsed with filtered seawater, and placed in scintillation vials with $5 \mathrm{ml}$ of scintillation cocktail (Liquiscint). Radioactive samples were counted at sea with the aid of a LKB 1217 scintillation counter interfaced with an Apple II microcomputer for data storage and manipulation (Prézelin et al. 1989).

For chl max samples using the Lewis system, $1 \mathrm{ml}$ aliquots were incubated with 30 to $50 \mu \mathrm{Ci} \mathrm{ml}{ }^{-1}$ of ${ }^{14} \mathrm{C}$ sodium bicarbonate in $7 \mathrm{ml}$ glass scintillation vials. The spectral characteristics of the interference filters were identical to those described above, covering the visible spectrum between 400 and $675 \mathrm{~nm}$. At each wavelength, samples were incubated at 8 different irradiances. After $1 \mathrm{~h}$, radioactive uptake was stopped by acidification and excess radiolabel was driven off by aerating samples on a shaking table for $1 \mathrm{~h}$ in a fume hood (Lewis et al. 1985). Five $\mathrm{ml}$ scintillation fluor was added and radiolabelled counts were made at sea.

For all $\mathrm{C}$-action spectra, the light-limited slope $\left[\alpha\left(\Delta \lambda_{1,} z\right)\right]$ of the spectral P-I relationships was determined by linear regression at each spectral bandwidth. Data was plotted to show \pm 1 standard error (SE) of the $\alpha\left(\Delta \lambda_{1}, z\right)$ estimate (Lewis et al. 1985). Estimates of in situ spectral production rates $[P(\Delta \lambda, z)$; Schofield et al. 1990] were derived for each photosynthetron waveband interval as a product of $\alpha\left(\Delta \lambda_{i}, z\right)$ and $Q_{d}\left(\Delta \lambda_{1}, z\right)$,

$$
P\left(\Delta \lambda_{i}, z\right)=\alpha\left(\Delta \lambda_{i}, Z\right) \cdot Q_{d}\left(\Delta \lambda_{1}, z\right)
$$

where spectral $Q_{d}\left(\Delta \lambda_{1}, z\right)$, rather than $A Q_{p h}\left(\Delta \lambda_{1}, z\right)$, values were used since $\alpha$ values are based on incident radiation. Upper limits on $P\left(\Delta \lambda_{i}, z\right)$ were imposed by not allowing the integrated sum of all $P\left(\Delta \lambda_{i}, z\right)$ to exceed white light estimates of $P(z)$ (Eq. 4) determined on replicate samples. This was done since low light levels in the spectral photosynthetron do not provide a spectral estimate of the photosynthetic potential and nor do they allow a means of measuring a light saturation parameter. When the integrated sum of $P\left(\Delta \lambda_{i}, z\right)$ exceeded $P(z)$ the spectral production values were reduced in all wavebands without changing the wavelength dependence.

$$
P(z)=P_{\max }(z) \cdot \tanh \left[Q_{\text {par }}(z) / I_{k}(z)\right]=\sum_{i=1}^{13} P\left(\Delta \lambda_{1}, z\right)
$$

This equivalence between $P(z)$ and the sum $P\left(\Delta \lambda_{i}, z\right)$ has been shown to be true for light-limited laboratory cultures of Synechococcus (Boucher pers. comm.) as well as a diatom and prymnesiophyte species (Schofield et al. 1990). This approach allowed us to link measurements of spectral photosynthesis to those derived from broadband P.I measurements of primary productivity. Using the approach for estimating the daily variability in P-I parameters and $P(z)$ (see above), it was possible to estimate hourly variations in $P\left(\Delta \lambda_{i}, z\right)$ and thereby provide simulated synoptic comparisons of noontime productivity rates for different phytoplankton communities sampled over a single day.

$\phi_{\text {max }}\left(\Delta \lambda_{i}, z\right)$ and $\phi\left(\Delta \lambda_{i}, z\right)$ : Estimates of maximum spectral quantum yield $\phi_{\max }\left(\Delta \lambda_{11} z\right)$ were calculated for thirteen $25 \mathrm{~nm}$ waveband intervals by dividing $\alpha\left(\Delta \lambda_{1}, z\right)$ by phytoplankton absorption, such that

$$
\phi_{\max }\left(\Delta \lambda_{i}, z\right)=\frac{\alpha\left(\Delta \lambda_{1}, Z\right)}{a_{\mathrm{ph}}\left(\Delta \lambda_{i}, z\right)}
$$

Given the linearity of the dilution series for absorption data and the reproducibility of the spectral irradiance measurements, the error in $\phi_{\max }\left(\Delta \lambda_{j} z\right)$ is most likely associated with the error in the $\alpha\left(\Delta \lambda_{j}, z\right)$ estimates shown in plots of C-action spectra (Figs. $4 \& 5$ ).

Estimates of in situ spectral quantum yield $\left[\phi\left(\Delta \lambda_{i}, z\right)\right]$ were derived from Eq. (1), where quantum yield can 
be derived from the real time production rates and photosynthetically absorbed light of the phytoplankton. Thus

$$
\phi\left(\Delta \lambda_{1}, z\right)=\frac{P\left(\Delta \lambda_{1,}, z\right)}{A Q_{\mathrm{ph}}\left(\Delta \lambda_{i,} z\right) \cdot 12000}
$$

where the ratio $\phi\left(\Delta \lambda_{i 1} z\right) / \phi_{\max }\left(\Delta \lambda_{n} z\right)$ indicated what fraction of the quantum yield potential was realized at any given time or location.

$\boldsymbol{\epsilon}\left(\Delta \lambda_{i}, Z\right)$ : An estimate of the spectral dependency of the radiation utilization efficiency $(\epsilon)$ was calculated as

$$
\epsilon\left(\Delta \lambda_{1}, z\right)=\frac{163.8 P\left(\Delta \lambda_{i}, z\right)}{K_{d}\left(\Delta \lambda_{i}, z\right) \cdot Q_{d}\left(\Delta \lambda_{1}, z\right)} \cdot 100
$$

where $K_{d}\left(\Delta \lambda_{1}, z\right)$ is the spectral downwelling diffuse attenuation coefficient, and 163.8 converts $1 \mathrm{mg} \mathrm{C}$ to its energy equivalent in $\mu$ Ein (Morel 1978, Kirk 1983, Smith et al. 1987).

\section{RESULTS}

Intensive vertical profiling of the physical properties of the Watercolors '88 study area (Fig. 1) provided hydrographic data which indicated the offshore flow of the California Current (CC) from the north and nearshore flow of Southern California Counter Current (SCCC) from the south, with episodic intrusions of upwelled water flowing from the northeast near Pt. Conception (Smith et al. 1990). The present study is based on one east-west transect in the study area completed between dawn and dusk of a single day. Three of the 4 transect stations (Stns 9.02,10.02 \& 11.01) were located within the SCCC. The surface waters of the fourth station (Stn 12.01) were hydrographically and biologically similar to the other 3 stations, while the chl max community was hydrographically distinct and appeared to represent a post bloom community of diatoms that subducted from upwelled waters off Pt. Conception (Smith et al. 1990, unpubl. data). A comparison of the physical, chemical and production values for the 4 transect stations is presented in Table 1.

\section{Optical, hydrographic and phytoplankton commun- ity characteristics of transect stations (Table 1)}

Density contours (Smith et al. 1990) indicated vertical stratification between surface and chl max phytoplankton communities at all stations on July 23 (Julian day 205). Moving west along the transect, the depth of the euphotic zone ( $1 \%$ light level) shoaled from 55 to $35 \mathrm{~m}$ (Baker et al. 1990). Surface samples $(<2 \mathrm{~m}$ ) were exposed to light-saturating and photo-inhibitory levels of $Q_{\text {par }}$ for most of the day, while chl max communities experienced a diurnal oscillation in $Q_{\text {par }}$ that lightsaturated rates of photosynthesis for only a few hours around midday (Boucher et al. 1990, Prezelin unpubl).

For surface communities along the east to west transect, water temperature fell $3.6^{\circ} \mathrm{C}$; salinity declined from between 33.75 and $33.65 \%$ at Stns $9.02,10.02$ \& 11.01 to $33.45 \%$ at $\operatorname{Stn} 12.01$; nitrate concentrations rose from undetectable levels to $2 \mu \mathrm{M}_{i}$ and chl increased 2-fold (Table 1). At the 3 SCCC stations, more than $70 \%$ of surface chl was attributable to phytoplankton communities $(0.4$ to $5.0 \mu \mathrm{m})$ comprised mostly of prymnesiophytes, cyanobacteria and green algae. In contrast, abundant phycoerythrin (PE)-rich cyanobacteria dominated surface waters at Stn 12.01. The $>5.0 \mu \mathrm{m}$ netphytoplankton communities were comprised largely of diatoms at all stations (Sloan \& Bidigare 1990)

The 3 chl max communities sampled within the SCCC were all located at 25 to $30 \mathrm{~m}$, at the 14 to $20 \%$ light level and near the $15{ }^{\circ} \mathrm{C}$ isotherm (Table 1). Phytoplankton community compositions were similar and resembled that of surface waters (Sloan \& Bidigare 1990). There was an approximate $70: 30$ split of chl distribution between the 0.4 to $5.0 \mu \mathrm{m}$ and $>5 \mu \mathrm{m}$ phytoplankton size fractions respectively. However, while the chl biomass of these SCCC chl max communities was essentially the same $\left(0.74 \pm 0.08 \mathrm{mg} \mathrm{chl} \mathrm{m}{ }^{-3}\right)$, chl concentrations at the chl max were up to 5 -fold higher than surface values at the same locations. Within the chl max at Stn 12.01, chl was about twice as abundant as at SCCC stations and the phytoplankton community was dominaled by $>5.0 \mu \mathrm{m}$ diatoms, with prymnesiophytes enriched in the 0.4 to $5.0 \mu \mathrm{m}$ size class (Sloan \& Bidigare 1990).

A comparison of realtime vs noontime estimates of photosynthetic parameters for surface and chl max communities is provided in Table 1 . As evidenced by $P(z) / P_{\max }$ values near 1.0 , it appeared that surface phytoplankton communities were light-saturated at midday and photoinhibition effects were not evident until later in the day (Boucher et al. 1990, Prézelin unpubl.). For surface waters of the SCCC stations, midday chl-specific production $\left[P(z) \mathrm{chl}^{-1}\right]$ was essentially the same [i.e. $4.84 \pm 0.28 \mathrm{mg} \mathrm{C}(\mathrm{mg} \mathrm{chl})^{-1} \mathrm{~h}^{-1}$ ) at all stations and 2.6-fold greater than those measured for surface waters at $\operatorname{Stn} 12.01$. This observation can be linked directly to noontime estimates of light-saturated photosynthetic potential, i.e. $P_{\max } \mathrm{chl}^{-1}$. There was a similar spatial variability in noontime estimates of $\alpha \mathrm{chl}^{-1}$. Noontime $I_{k}$ values varied 3 -fold in surface

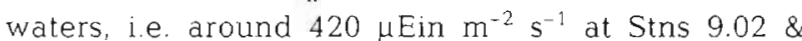

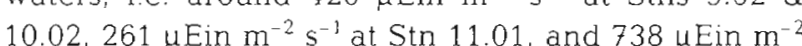
$\mathrm{s}^{-1}$ at $\mathrm{Stn} 12.01$. 
Estimates of the noontime $P(z) \mathrm{chl}^{-1}$ for chl max communities (Table 1) were up to 7 -fold lower than similar estimates for surface communities at the same station, in spite of the observation that these communities were photosynthesizing at or near light saturation [i.e. noontime $P(z) / P_{\max }$ ratios between 0.64 and 1). Compared to surface communities, chl max communities were characterized by significantly lower estimates for $P_{\max } \mathrm{chl}^{-1}$ and $I_{k}$. Between different chl max communities, $I_{k}$ values steadily declined 2.6 -fold across the transect and were coincident with observations that chl maxima occur at lower light depths across the transect. Along the same spatial gradient, $P_{\max } \mathrm{Chl}^{-1}$ values declined 2 -fold. Estimates of $P(z)$ $\mathrm{chl}^{-1}$ were highest in the chl max at Stn 10.02 [1.25 mg $C\left(m g c^{-1} h^{-1}\right.$ l and 3-fold lower at Stn 12.01 $\left[0.47 \mathrm{mg} \mathrm{C}(\mathrm{mg} \mathrm{chl})^{-1} \mathrm{~h}^{-1}\right]$.

\section{Absorption-based productivity parameters}

$$
a_{\mathrm{ph}}(\lambda, z) \mathrm{chl}^{-1} \text { and } \alpha\left(\Delta \lambda_{\prime \prime} z\right) \mathrm{chl}^{-1}
$$

Particle absorption spectra were corrected for detrital absorption and allowed direct comparisons of the absorption properties for different phytoplankton communities. Chl-specific absorption varied 2- to 3fold in the surface phytoplankton communities, with highest chl-specific absorption evident in the oligotrophic waters of the SCCC (Fig. 4). The majority of the spatial variability in phytoplankton absorption was attributable to the variations in the magnitude of chl-specific blue light absorption (400 to $500 \mathrm{~nm}$ ). Interestingly, chl-specific red light absorption $\mid a_{\mathrm{ph}}(675)$ $\mathrm{chl}^{-1}$ ] declined almost 4 -fold along the transect of the $3 \mathrm{SCCC}$ stations, from a high of $0.038 \mathrm{~m}^{2} \mathrm{mg} \mathrm{chl}^{-1}$ at Stn 9.02 to $0.01 \mathrm{~m}^{2} \mathrm{mg} \mathrm{chl}^{-1}$ at Stn 11.01. The $a_{\mathrm{ph}}(675)$ $\mathrm{chl}^{-1}$ value for surface waters of $\mathrm{Stn} 12.01$ was $0.006 \mathrm{~m}^{2} \mathrm{mg} \mathrm{chl} \mathrm{ch}^{-1}$. The $\mathrm{a}_{\mathrm{ph}} \mathrm{chl}^{-1}$ for chl max communities (Fig. 5) varied 3 -fold across the transect. Highest $a_{\mathrm{ph}}(\lambda, z) \mathrm{chl}^{-1}$ values occurred at Stn 10.02 , where the chl max was in a higher light environment and at warmer temperature than chl max communities at the other 3 stations (Table 1 ). Lowest $a_{\mathrm{ph}}(\lambda, z) \mathrm{chl}^{-1}$ values were observed for diatom-dominated chl max communities at $\operatorname{Stn} 12.01$, i.e. $a_{\mathrm{ph}}(675) \mathrm{chl}^{-1}=0.011 \mathrm{~m}^{2}$ $(\mathrm{mg} \mathrm{chl})^{-1}$ and an $a_{\mathrm{ph}} \mathrm{chl}^{-1}(425$ to 450$)=0.028 \mathrm{~m}^{2}$ (mg chl) $)^{-1}$. There was no evident relationship between $a_{\mathrm{pn}}(\lambda, z) \mathrm{chl}^{-1}$ in the surface and chl max communities.

Figs. $4 \& 5$ also illustrate the variability in the spectral dependency of light-limited slope of photosyn-
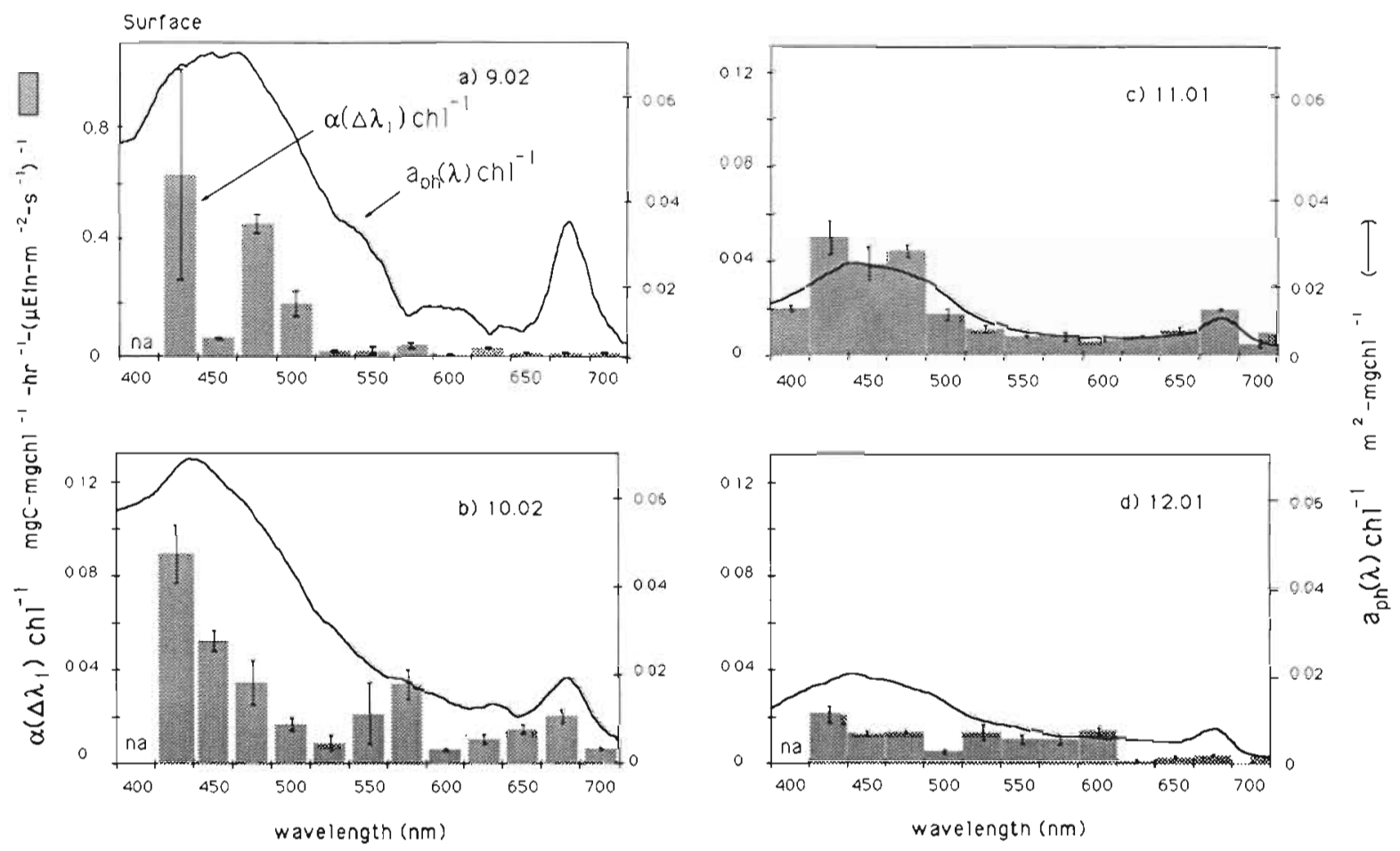

Fig. 4. Comparison of surface detrital-corrected phytoplankton absorption $\left[a_{\mathrm{ph}}(\lambda, z) \mathrm{chl}^{-1}\right.$, solid line $\mid$ and light-limited slope of photosynthesis $\left[\alpha\left(\Delta \lambda_{1}, z\right) \mathrm{chl}^{-1}\right.$, bars] for $>0.4 \mu \mathrm{m}$ phytoplankton communities. Samples were collected at different times of the day at 4 transect hydrocasts on July 23, 1988. Vertical lines indicate \pm 1 SE of $\alpha\left(\Delta \lambda_{1}, z\right)$ chl $^{-1}$ values. Note scale changes. na: not available 

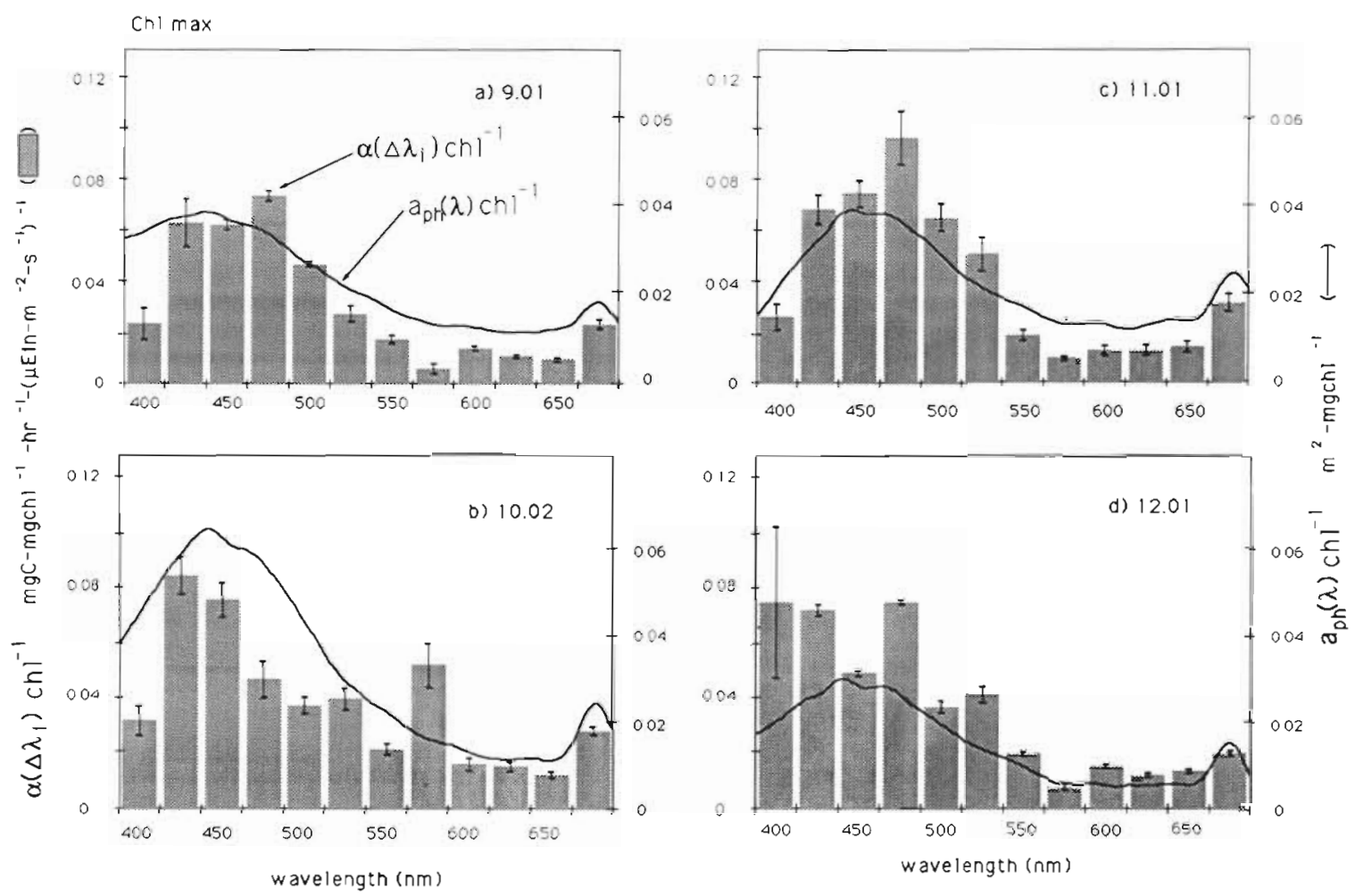

Fig. 5. Comparison of chl max detrital-corrected phytoplankton absorption $\left[\mathrm{a}_{\mathrm{ph}}(\lambda, z) \mathrm{chl}^{-1}\right.$, solid line] and light-limited slope of photosynthesis $\left[\alpha\left(\lambda \lambda_{1}, z\right) c h l^{-1}\right.$, bars] for phytoplankton communities collected at different times of day at 4 transect hydrocasts on July 23, 1988. Vertical lines indicate \pm 1 SE of $\alpha\left(\Delta \lambda_{i}, z\right) c h l^{-1}$ values

thesis $\left[\alpha\left(\Delta \lambda_{i} z\right) \mathrm{chl}^{-1}\right]$ at each location and provide a direct comparison of the $\mathrm{C}$-action spectra with the phytoplankton absorption properties $\left[a_{\mathrm{ph}}(\lambda, z) \mathrm{chl}^{-1}\right]$. Surface communities displayed a greater variability in $\alpha\left(\Delta \lambda_{i l} z\right) \mathrm{chl}^{-1}$ than did chl max communities. Highest bluegreen (400 to $500 \mathrm{~nm}) \alpha\left(\Delta \lambda_{i l} z\right)$ values were evident at $\operatorname{Stn} 9.02$ and were up to an order of magnitude greater than comparable measurements at the other 3 stations. Within the SCCC, bluegreen light absorption appeared to support the largest fraction of $\alpha\left(\Delta \lambda_{i}, z\right) \mathrm{chl}^{-1}$. In contrast, $\alpha\left(\Delta \lambda_{j}, z\right) \mathrm{chl}^{-1}$ in the Synechococcus-dominated surface community at Stn 12.01 was equally supported by $a_{\mathrm{ph}}(\lambda, z) \mathrm{chl}^{-1}$ attributable to chl and carotenoid absorption between 400 and $500 \mathrm{~nm}$ and phycobilin absorption between 525 and $600 \mathrm{~nm}$.

The carbon action spectra for all chl max communities within the SCCC were generally similar in shape and magnitude (Fig. 5a to c). The carbon action spectrum for the chl max at Stn 12.01 (Fig. 5d) differed from the others in that bluegreen $\left.\alpha(\lrcorner \lambda_{1}, z\right) \mathrm{chl}^{-1}$ values were highest at wavebands not attributable to chl a absorption. The ratio of the bluegreen ( 450 to 525 ) to red (625 to 672) wavebands was 2 -fold higher for the diatomdominated community then the SCCC chl max communities.

$$
A Q_{\mathrm{ph}}\left(\Delta \lambda_{i}, z\right), A Q_{\mathrm{ph}}(z) \text { and } P\left(\Delta \lambda_{i}, z\right)
$$

Figs. 6 \& 7 compare noontime estimates of in situ light absorption $\left[A Q_{\mathrm{ph}}\left(\Delta \lambda_{1}, z\right)\right]$ for the different phytoplankton communities. In surface waters (Fig. 6), the spectral shape of $A Q_{p h}\left(\Delta \lambda_{\mu} z\right)$ closely resembled the $a_{\mathrm{ph}}(\lambda, z) \mathrm{chl}^{-1}$ spectrum (Fig. 4). Values of $A Q_{\mathrm{ph}}\left(\Delta \lambda_{1}, z\right)$ peaked in the blue region of the visible spectrum, and varied $27 \%$ (range from 0.0037 to $0.0027 \mathrm{Ein} \mathrm{m}^{-3} \mathrm{~h}^{-1}$ ) (Fig. 6). For chl max communities (Fig 7), $A Q_{\mathrm{ph}}\left(\Delta \lambda_{i} z\right.$ ) more closely resembled the underwater light field than the absorption properties of the phytoplankton (Fig. 5). Highest $A Q_{\mathrm{ph}}\left(\Delta \lambda_{1}, z\right)$ values were centered at bluegreen wavelengths and no detectable red light absorption was evident (Fig. 7). For chl max communities within the SCCC, $A Q_{\mathrm{ph}}\left(\Delta \lambda_{1}, z\right)$ values varied 2 - to 3 -fold (ranged from 0.0070 to $0.0020 \mathrm{Ein} \mathrm{m}^{-3} \mathrm{~s}^{-1}$ ). The lowest $A Q_{\mathrm{ph}}\left(\Delta \lambda_{1}, z\right)$ values were observed in the chl max of the postupwelled waters of Stn 12.01 (Fig. 7).

Spectral production was calculated according to Eq. (6) and is presented in Figs. 6 \& 7. In surface waters, production rates were highest in the blue and green wavelengths ( 400 to $475 \mathrm{~nm}$ ) and ranged 3 -fold when $P\left(\Delta \lambda_{j} z\right) \mathrm{Chl}^{-1}$ was integrated over $Q_{\text {par }}$. Within the surface waters, light absorbed between 400 and $500 \mathrm{~nm}$ accounted for 56 to $89 \%$ of in situ productivity 

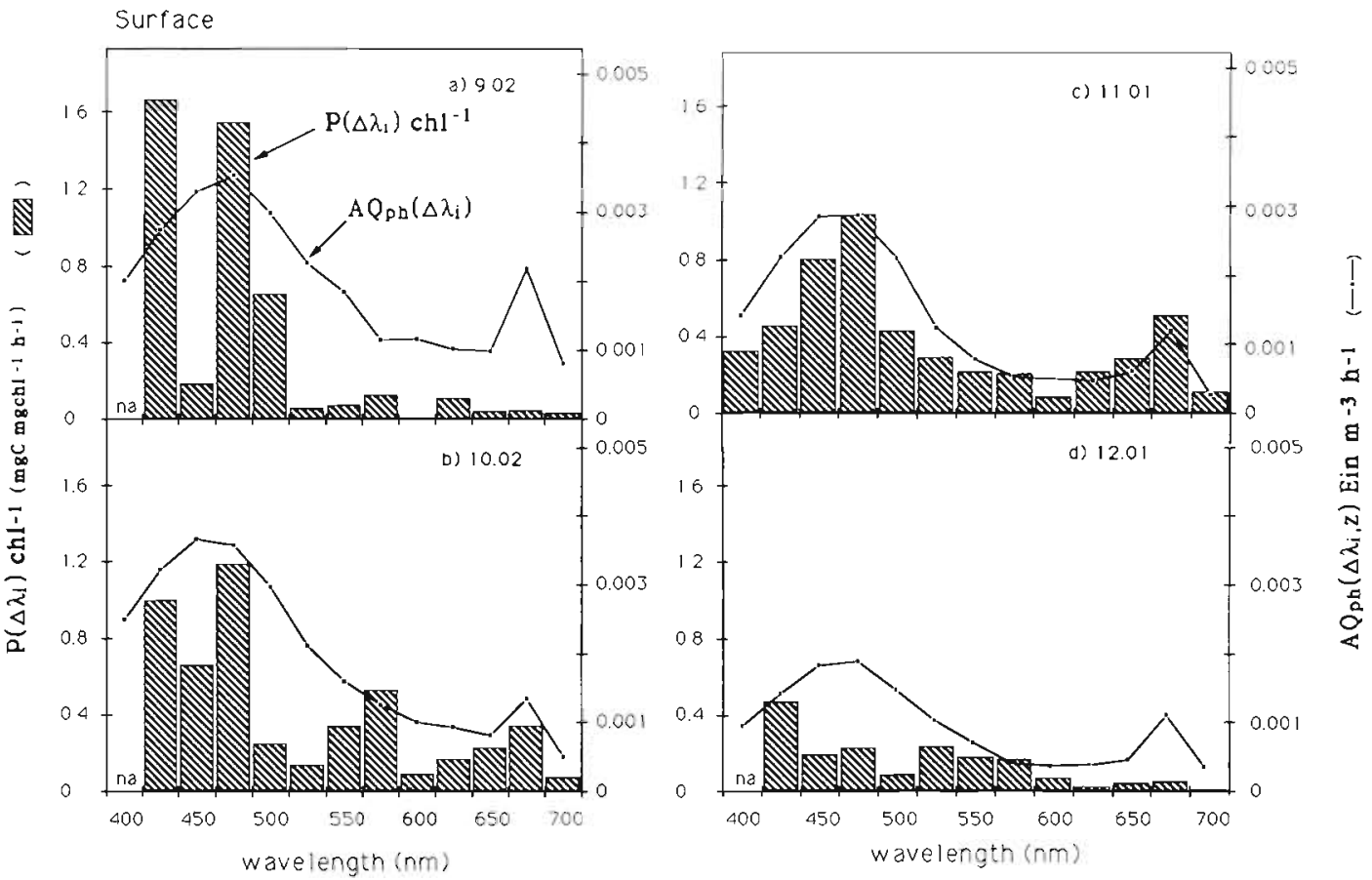

Fig. 6. Comparison of noontime surface estimates of in situ $A Q_{\mathrm{ph}}\left(\Delta \lambda_{1}, z\right)$ (solid line) and chl-specific rates of spectral photosynthesis (bars) for $>0.4 \mu \mathrm{m}$ phytoplankton communities collected at 4 Southern California Bight transect hydrocasts on July 23 , 1988

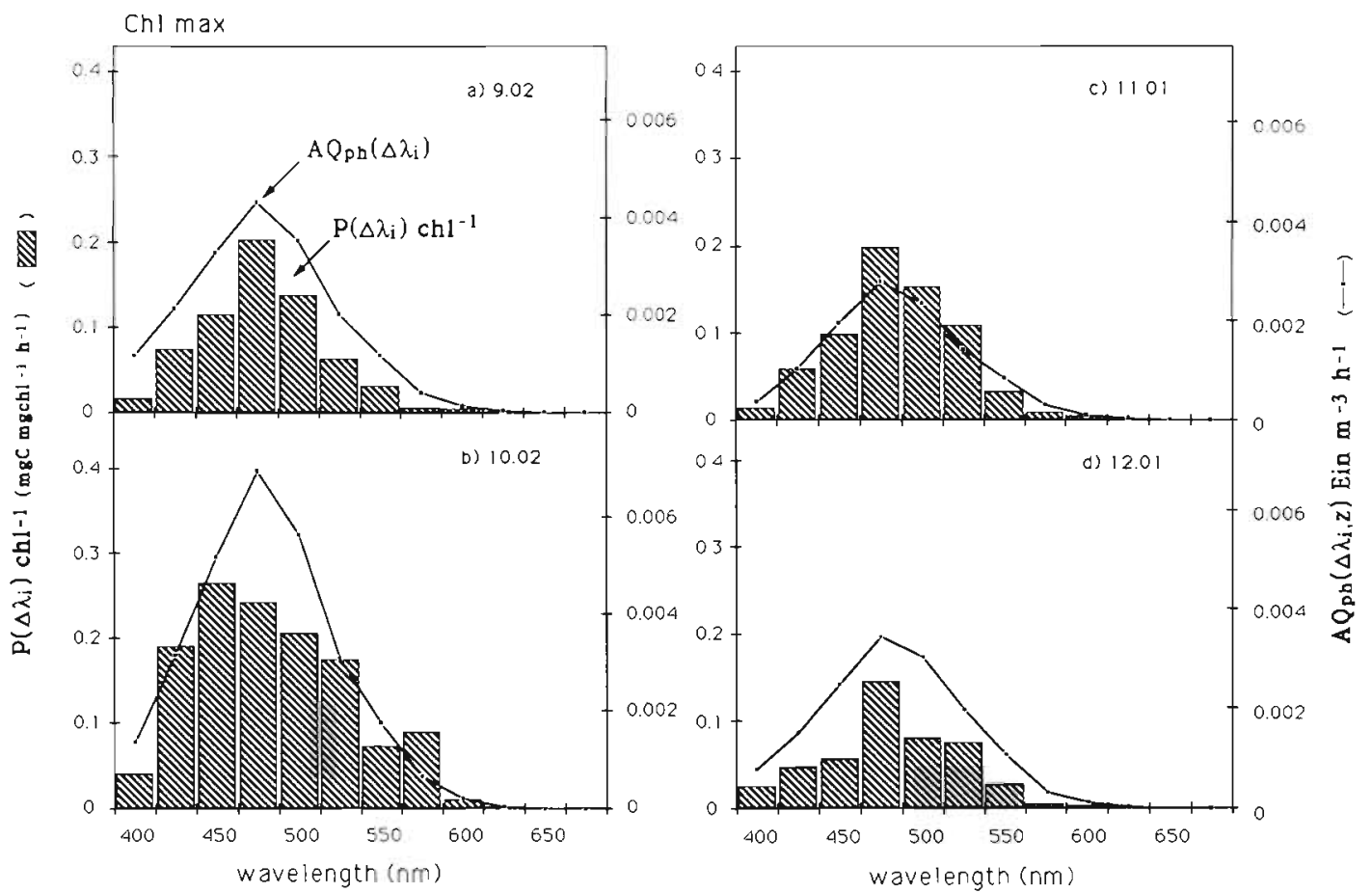

Fig. 7. Comparison of noontime chl max estimates of in situ $A Q_{p h}\left(\Delta \lambda_{1} z\right)$ (solid line) and chl-specific rates of spectral photosynthesis (bars) for total phytoplankton communities collected from 4 Southern California Bight transect hydrocasts on July 23 , 


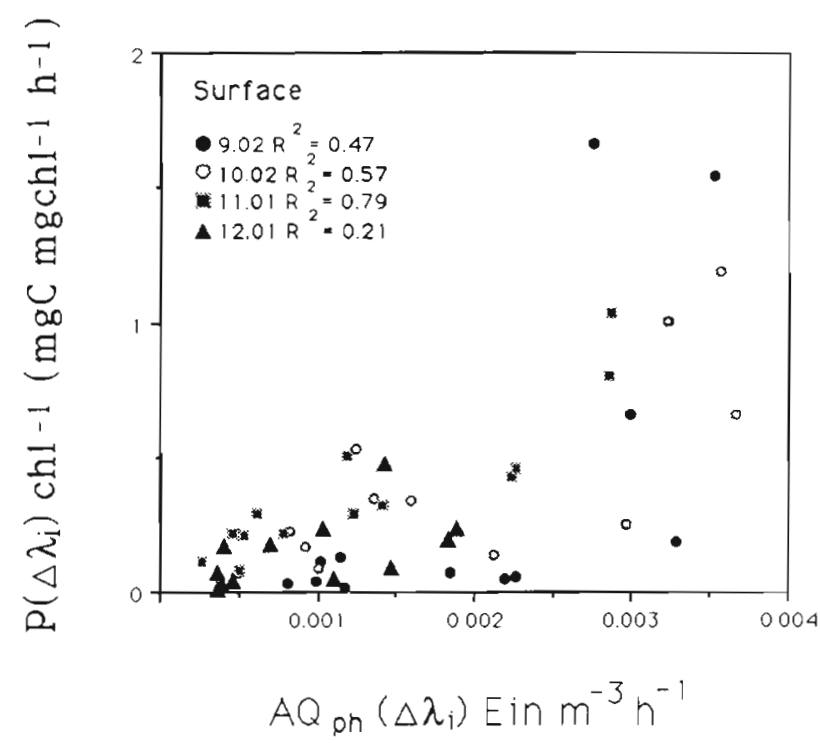

Fig. 8. Comparison of the spectral relationship between $P\left(\Delta \lambda_{i}, z\right) \mathrm{chl}^{-1}$ and $A Q_{\mathrm{ph}}\left(\Delta \lambda_{i}, z\right)$ at all visible wavebands for noontime normalized spectra for surface phytoplankton communities sampled from 4 transect hydrocasts on July 23, 1988

rates (Fig. 6); light between 525 and $600 \mathrm{~nm}$ accounted for 6 to $36 \%$ of the in situ productivity (Fig. 6); while 5 to $23 \%$ of the in situ productivity was driven by light absorbed between 625 and $675 \mathrm{~nm}$ (Fig. 6). Chl-specific production rates were similar at the $3 \mathrm{SCCC}$ stations (9.02, 10.02, \& 11.01) and were 2.7-fold lower at Stn 12.01. At depth, carbon fixation was driven by blue and green wavelengths and varied 3-fold when $P\left(\Delta \lambda_{j 1} Z\right) \mathrm{chl}^{-1}$ was integrated over $Q_{\text {par }}$. Light absorbed between 400 and $500 \mathrm{~nm}$ at the chl max accounted for 73 to $84 \%$ of the fixed carbon, with the remaining 16 to $27 \%$ of fixed carbon attributable to light absorbed between 525 and $600 \mathrm{~nm}$ (Fig. 7).

The spectral match between $A Q_{p h}\left(\Delta \lambda_{u} z\right)$ and $P\left(\Delta \lambda_{1}, z\right) \mathrm{chl}^{-1}$ values was consistently poor in surface waters, and no significant linear relationship between these spectral parameters was evident (Fig. 8). In contrast, a close linear correlation existed between these parameters in the chl max communities (Fig. 9) with an $\mathrm{R}^{2}$ of $0.88(n=48)$. However, the linear relationship between $P\left(\Delta \lambda_{j}, z\right) \mathrm{chl}^{-1}$ and $A Q_{\mathrm{ph}}\left(\Delta \lambda_{1}, z\right)$ changed over the day for chl max communities, primarily due to diurnal changes in quantum efficiency (Prézelin unpubl.).

\section{Quantum yield}

$$
\phi_{\max }\left(\Delta \lambda_{j,} z\right), \phi\left(\Delta \lambda_{j}, z\right), \text { and } \epsilon\left(\Delta \lambda_{i}, Z\right)
$$

Estimates of the maximum spectral quantum yield $\left[\phi_{\max }\left(\Delta \lambda_{1}, z\right)\right.$, mol $\left.\mathrm{C} \mathrm{Ein}^{-1}\right]$ were derived for surface waters (Fig. 10) and the chl max (Fig. 11). Values for

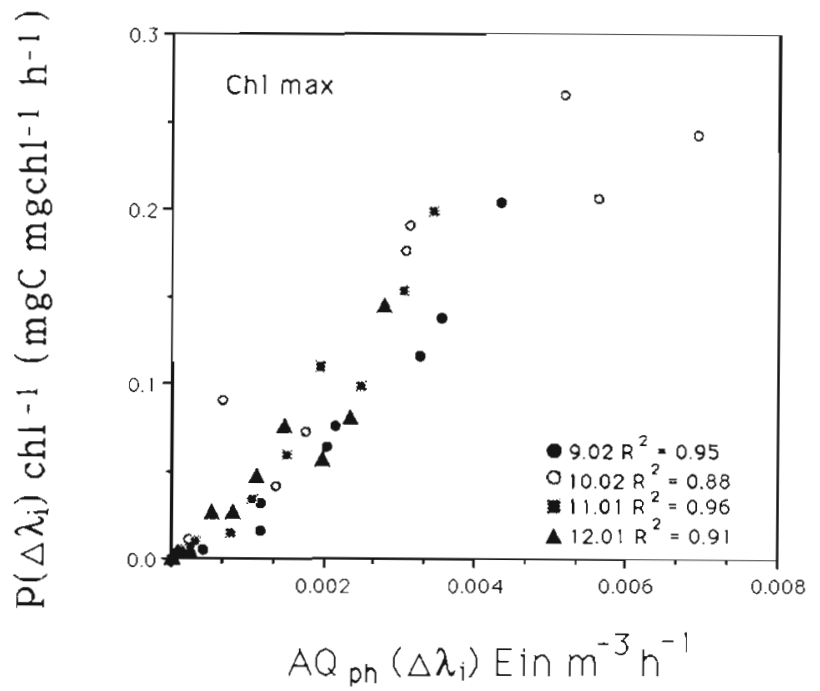

Fig. 9. Comparison of the spectral relationship between $P\left(\Delta \lambda_{j}, z\right) \mathrm{chl}^{-1}$ and $A Q_{\mathrm{ph}}\left(\Delta \lambda_{1}, z\right)$ at all visible wavebands for noontime normalized spectra for chl max phytoplankton communities sampled from 4 transect hydrocasts on July 23, 1988

$\phi_{\max }\left(\Delta \lambda_{t r} z\right)$ were spatially variable and often increased with depth. Values rarely approached the theoretical maximum for carbon fixation $\left(0.125 \mathrm{~mol} \mathrm{C} \mathrm{Ein}^{-1}\right)$. Exceptions were noted at blue wavelengths for surface communities at Stn 9.02 (Fig. 10a) and wavelengths associated with phycobilins at Stn 12.01 (Fig. 11d). Values of $\phi_{\max }\left(\Delta \lambda_{1}, z\right)$ at 425 and $475 \mathrm{~nm}$ at Stn 9.02 were too high and probably attributable to errors associated with low biomass and low photosynthetic activity at the time of early morning sampling. For this reason all parameters derived from $\alpha(\Delta \lambda, z) \mathrm{chl}^{-1}$ are suspect at 425 and $475 \mathrm{~nm}$ in the surface waters of $\operatorname{Stn} 9.02$. From east to west along the transect, the spectral signature of $\phi_{\max }\left(\Delta \lambda_{1}, z\right)$ in surface communities shifted from wavelengths dominated by chl absorption to those dominated phycobilin absorption. There were no evident trends in the spectrally averaged $\phi_{\max }\left(\Delta \lambda_{1}, z\right)$ within the SCCC. At the depth of the chl max, $\phi_{\max }\left(\Delta \lambda_{1}, Z\right)$ values ranged between 0.020 and 0.076 at the $3 \mathrm{SCCC}$ stations (Fig. $11 \mathrm{a}$ to $\mathrm{C}$ ) and were significantly higher at most wavebands at Stn 12.01 (Fig. 11d). There were no trends in the variability in the spectral shape of $\phi_{\max }\left(\Delta \lambda_{1} z\right)$ between the chl max communities across the transect.

For all depths and locations, $\phi\left(\Delta \lambda_{j}, z\right)$ values were always significantly lower than measured $\phi_{\max }\left(\Delta \lambda_{i l} z\right)$ values. However, $\phi\left(\Delta \lambda_{i}, z\right)$ and $\phi_{\max }\left(\Delta \lambda_{1}, z\right)$ spectra had similar spectral shapes within any given phytoplankton community (Figs. $10 \& 11$ ). In surface waters, $\phi\left(\Delta \lambda_{1}, z\right)$ values rarely exceeded $0.01 \mathrm{~mol} \mathrm{C} \mathrm{Ein}{ }^{-1}$ and showed a similar spatial variability as $\phi_{\max }\left(\Delta \lambda_{1} z\right)$. At the chl max, $\phi\left(\Delta \lambda_{i}, z\right)$ values ranged between 0.003 and $0.020 \mathrm{~mol} \mathrm{C} \mathrm{Ein}{ }^{-1}$ for the $3 \mathrm{SCCC}$ stations and were 

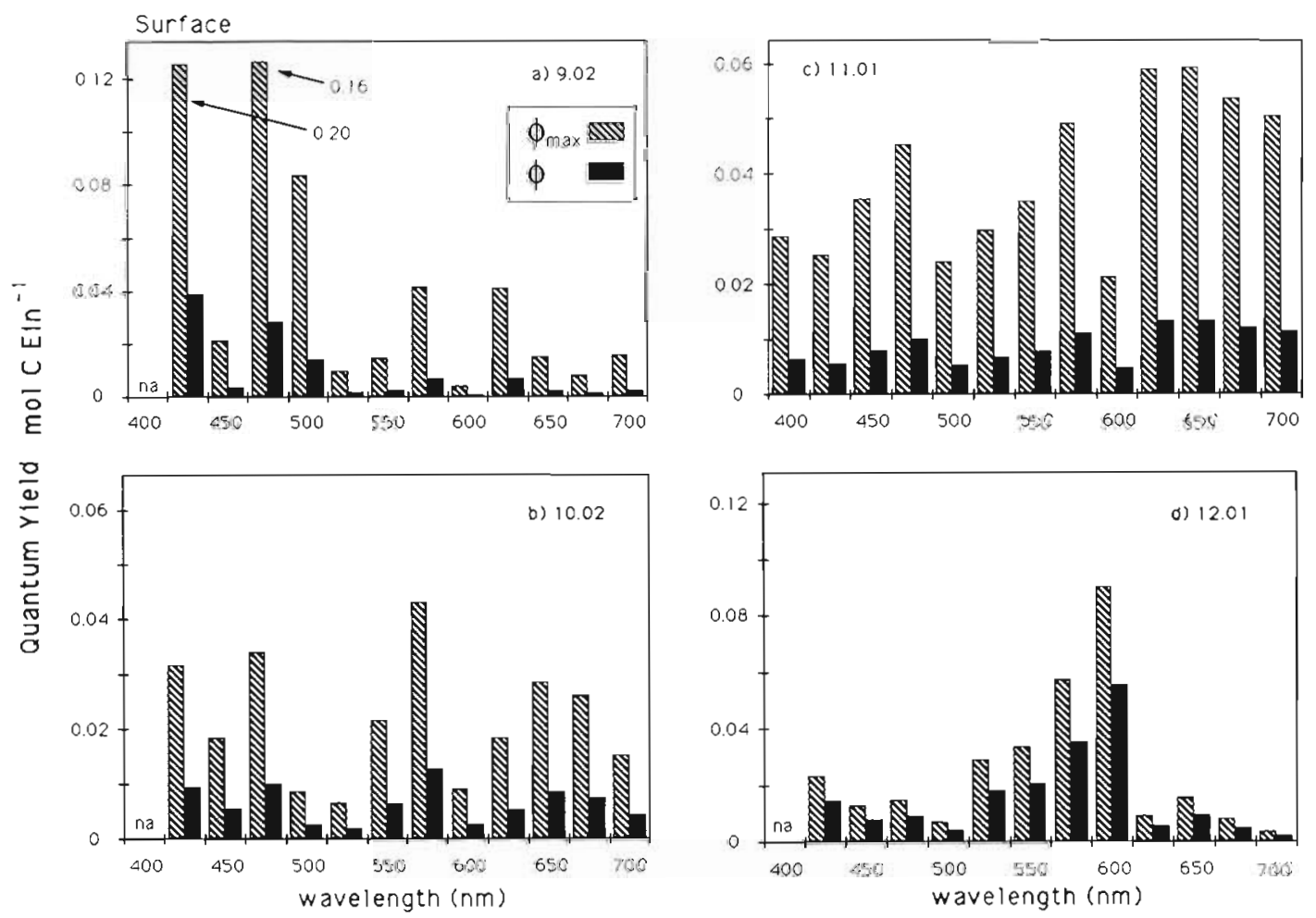

Fig. 10. Comparisons of spectrally measured surface $\phi_{\max }\left(\Delta \lambda_{1}, z\right)$ (striped bar) and derived estimates of $\phi\left(\Delta \lambda_{1}, z\right)$ (black bar) for $>0.4 \mu \mathrm{m}$ phytoplankton communities collected from 4 transect hydrocasts on July 23,1988 . Note scale change. na: not available
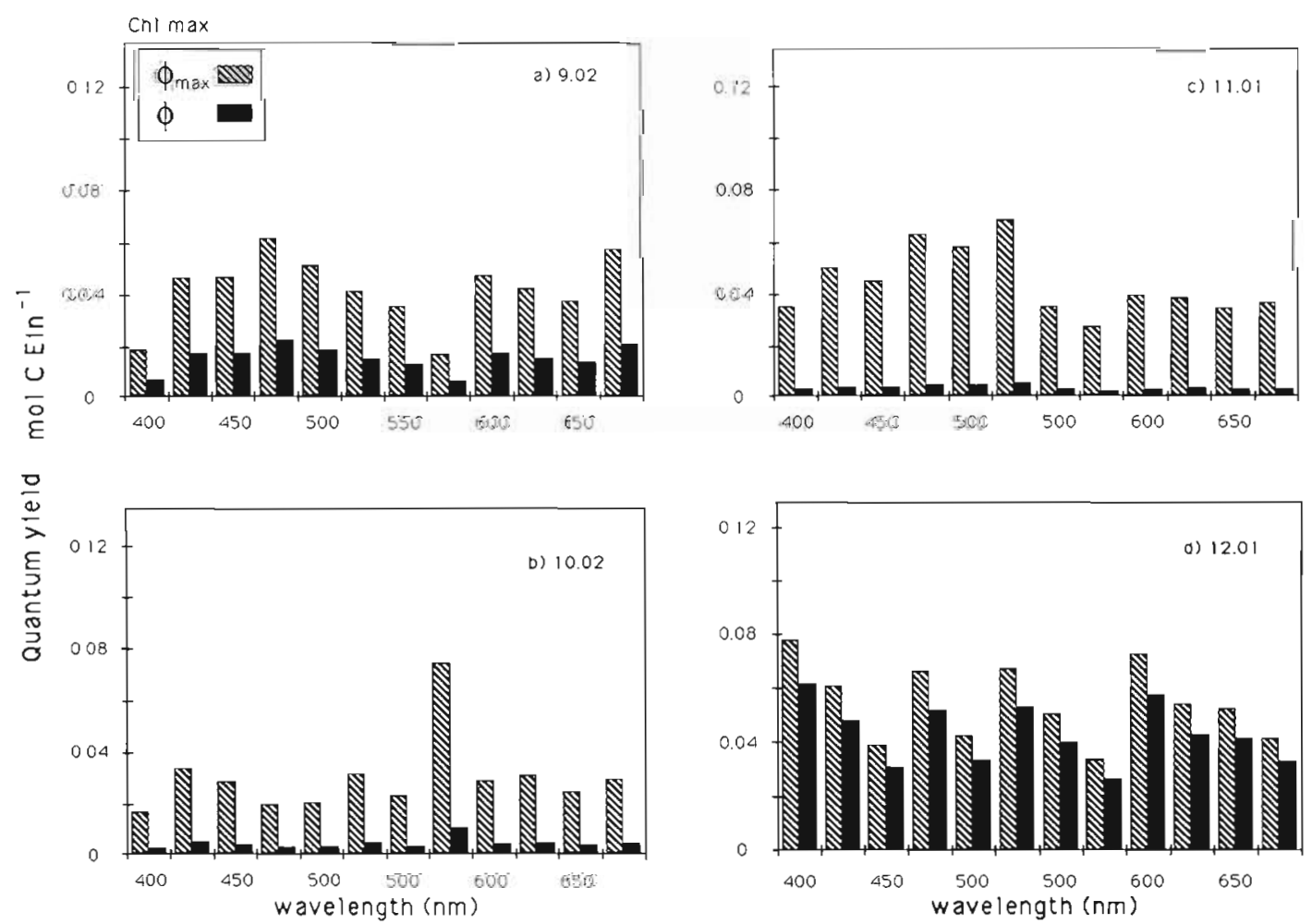

Fig. 11 Comparisons of spectrally measured chl max $\phi_{\max }\left(\Delta \lambda_{1}, z\right)$ (striped bar) and derived estimates of $\phi\left(\Delta \lambda_{1}, z\right)$ (black bar) for total phytoplankton communities collected from 4 transect hydrocasts on July 23, 1988 
Table 3. Comparison of different real-time estimates of relative photosynthetic efficiency at 4 transect stations sampled across the Southern California Bight on July 23, 1988. See Table 2 for definition of symbols

\begin{tabular}{|c|c|c|c|c|c|c|c|c|}
\hline & \multicolumn{4}{|c|}{ Surface } & \multicolumn{4}{|c|}{ Chl max } \\
\hline Cast no. & 9.02 & 10.02 & 11.01 & 12.01 & 9.02 & 10.02 & 11.01 & 12.01 \\
\hline$\alpha \mathrm{chl}^{-1}$ & 0.007 & 0.013 & 0.012 & 0.010 & 0.007 & 0.009 & 0.006 & 0.006 \\
\hline $\bar{\alpha}\left(\Delta \lambda_{1}, z\right) \mathrm{chl}^{-1}$ & 0.038 & 0.030 & 0.017 & 0.010 & 0.031 & 0.038 & 0.039 & 0.036 \\
\hline$\overline{\alpha_{(\mathrm{P}-1)}} \mathrm{chl}^{-1}$ & 0.045 & 0.019 & 0.012 & 0.007 & 0.019 & 0.029 & 0.027 & 0.021 \\
\hline$\frac{Q_{\text {PAR }}(z)}{I_{k}(z)}$ & 0.2 & 3.1 & 4.2 & 1.8 & 0.1 & 2.0 & 1.1 & 0.6 \\
\hline$\phi_{\max }(\mathrm{P}-1)$ & 0.004 & 0.010 & 0.025 & 0.023 & 0.008 & 0.005 & 0.006 & 0.008 \\
\hline$\overline{\phi_{\max }}\left(\Delta \lambda_{1}, z\right)$ & 0.025 & 0.022 & 0.040 & 0.025 & 0.041 & 0.030 & 0.044 & 0.055 \\
\hline $\bar{\phi}\left(\Delta \lambda_{j}, z\right)$ & 0.010 & 0.006 & 0.009 & 0.016 & 0.015 & 0.004 & 0.003 & 0.043 \\
\hline$\frac{\phi\left(\Delta \lambda_{1,}, z\right)}{\phi_{\max }\left(\Delta \lambda_{1}, z\right)}$ & $40 \%$ & $27 \%$ & $23 \%$ & $61 \%$ & $36 \%$ & $13 \%$ & $7 \%$ & $79 \%$ \\
\hline
\end{tabular}

highest at the post-upwelling station. It is also noted that $\phi\left(\Delta \lambda_{1}, z\right)$ approached $\phi_{\max }\left(\Delta \lambda_{j}, z\right)$ in the early morning (Stn 9.02) and late evening (Stn 12.01) (Table 3) when these communities were clearly light-limited ji.e. $P(z) \ll P_{\text {max }} ;$ Table 1$]$.

Lastly, spectral production values were recast to provide the first known estimates of the spectral radiation utilization efficiency $\left[\epsilon\left(\Delta \lambda_{1}, z\right)\right]$ (Fig. 12). Highest values of $\epsilon\left(\Delta \lambda_{i}, z\right)$ were observed for bluegreen light in the surface waters, with 425 to $475 \mathrm{~nm}$ wavebands accounting for up to $80 \%$ of the utilized radiation. In surface waters bluegreen $\epsilon\left(\Delta \lambda_{i}, z\right)$ values at SCCC stations approached $0.2 \%$, while similar estimates were only $0.03 \%$ at $\operatorname{Stn} 12.01$ (Fig. 12a). Maximum values of $\epsilon\left(\Delta \lambda_{1}, z\right)$ in the chl max communities were similar to the surface waters; however unlike the surface communities maximum values of $\epsilon\left(\Delta \lambda_{1}, z\right)$ were observed in the wavebands associated with accessory chlorophylls ( $b$, c) and carotenoid absorption.

\section{DISCUSSION}

Phytoplankton exhibit a high degree of physiological plasticity which enables them to optimize production and growth in highly variable regions of the ocean (cf Stewart 1974, Morris 1980, Platt 1986, Prézelin et al. 1991). Photosynthetic adaptation in most phytoplankton is clearly reflected in measurable changes in cellular bio-optical properties fi.e. absorption, fluorescence, quantum yield, light-saturation requirements for photosynthesis and photoinhibition, etc.) (cf. Prézelin 1981, Richardson et al. 1983, Prézelin \& Boczar 1986, and others) that are key components in current

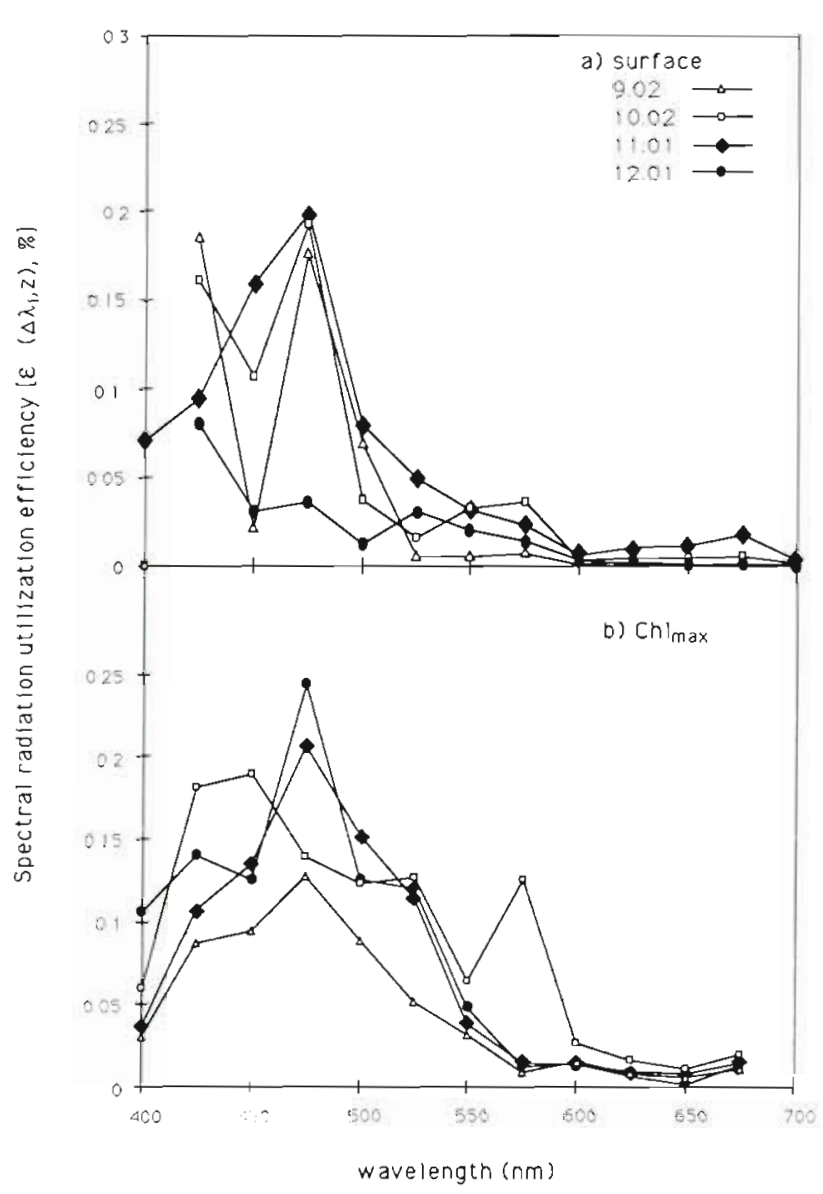

Fig. 12. Comparison of noontime estimates of spectral radiation utilization efficiency $\left[\epsilon\left(\triangle \lambda_{n} z\right], \%\right]$ for surface and $c h l$ max phytoplankton communities sampled from 4 transect hydrocasts on July 23,1988 
bio-optical models of primary production. Currently there is a need to quantify the natural variability in the bio-optical properties of phytoplankton, especially those related to the light utilization efficiencies. The quantitative relationships between spectral and nonspectral estimates of these bio-optical parameters need to be defined for natural phytoplankton communities. This will allow production models to incorporate the spectral properties of phytoplankton which will increase the ability of production models to accommodate changes in phytoplankton composition, pigmentation and quantum yield (Smith et al. 1989b).

\section{Hydrography and community state}

Variability in and between the phytoplankton communities appeared to be linked to the hydrographic variability within the transect. The oligotrophic and vertically stratified water columns of the SCCC at the east end of the transect (Stns $9.02 \& 10.02$ ) were populated with picoplankton communities. Despite their designation as low productivity environments the phytoplankton in these waters had chl-specific photosynthetic rates which exceeded those found in the colder nutrient-rich waters to the west (Table 1). The relatively high assimilation rates we observed are similar to those recently reported for picoplanktondominated communities of warm oligotrophic waters, including the subtropical gyre of the North Pacific (Laws et al. 1987), the eastern Banda Sea (Gieskes et al. 1990), the Sargasso Sea (Iturriaga \& Marra 1988, Prézelin \& Glover 1991), and a warm-core eddy in the Northwest Atlantic (Prézelin et al. 1986). Taken alone, the high chl-specific photosynthetic rates of picoplankton can be interpreted as either an indication of rapid growth (cf. Glover et al. 1988, Prézelin et al. 1989) and/or an indication of high light adaptation accompa- nied with a decline in cellular chl (cf. Prézelin et al. 1981). Higher chl-specific photosynthetic rates were accompanied by higher ph $(\lambda) \mathrm{chl}^{-1}$ and $A Q_{\text {ph }}(z)$ values (Table 4). Furthermore these phytoplankton maintained quantum yields equal or exceeding those in phytoplankton communities localized within more nutrient-rich and colder waters to the west (Table 4). This suggests the phytoplankton communities in the SCCC were metabolically active and were bright-light adapted.

Horizontal gradients in temperature and nutrients along the transect corresponded to a shift in phytoplankton communities. The change was evident at Stn 12.01, where there was a shift to a Synechococcusenriched community mixed with net-phytoplankton in surface waters and the presence of a large community of diatoms within the chl max. Compared to the other transect stations, there was a significantly smaller $A Q_{\mathrm{ph}}(z)$ in both surface and chl max communities at Stn 12.01 (Table 4). Decreased chl-specific absorption may indicate enriched intracellular pigment concentrations along with a corresponding package effect (cf. Kirk 1983). The photosynthetic physiology however suggested that the phytoplankton at Stn 12.01 were physiologically stressed even though detectable levels of nitrate were available (Table 1). The light-saturated surface phytoplankton had assimilation rates of $<2 \mathrm{mg}$ $\mathrm{C}(\mathrm{mg} \mathrm{chl})^{-1} \mathrm{~h}^{-1}$, yet had a higher light requirement for photosynthesis $\left(I_{k}\right)$ than any other community sampled (Table 1).

\section{Utilization of light by phytoplankton}

The present study showed that values for spectral and nonspectral $\phi$ rarely approached comparable estimates for $\phi_{\max }$ (Table 4) which, in turn, was routinely less than half the theoretical upper limit of $\phi_{\max }(0.1$ to

Table 4. Comparison of midday values derived for several bio-optical production parameters determined at 4 transect stations sampled across the Southern California Bight on July 23, 1988. See Table 2 for definition of symbols

\begin{tabular}{|c|c|c|c|c|c|c|}
\hline Stn & $\begin{array}{c}Q_{\text {pur }} \\
\left(\mu \operatorname{Ein} \mathrm{m}^{-2} \mathrm{~s}^{-1}\right)\end{array}$ & $\begin{array}{c}\overline{a_{\mathrm{ph}}}(\lambda) \mathrm{chl}^{-1} \\
{\left[\mathrm{~m}^{2}(\mathrm{mg} \mathrm{chl})^{-1}\right]}\end{array}$ & $\begin{array}{c}A Q_{p h} \\
\left(\text { Ein } \mathrm{m}^{-3} \mathrm{~h}^{-1}\right)\end{array}$ & $\begin{array}{c}\left.\bar{\phi}(\lrcorner \lambda_{l}\right) \\
\left(\mathrm{mol} \mathrm{CEin}{ }^{-1}\right)\end{array}$ & $\begin{array}{c}P \mathrm{chl}^{-1} \\
{\left[\mathrm{mg} \mathrm{C}\left(\mathrm{mg} \mathrm{chl}^{-1} \mathrm{~h}^{-1}\right]\right.}\end{array}$ & $\begin{array}{c}\bar{\epsilon}\left(\Delta \lambda_{1}\right) \\
(\%)\end{array}$ \\
\hline \multicolumn{7}{|l|}{ Suriace } \\
\hline 9.02 & 1222 & 0.036 & 0.026 & 0.002 & 4.55 & 0.039 \\
\hline 10.02 & 1367 & 0.030 & 0.025 & 0.003 & 5.01 & 0.050 \\
\hline 11.01 & 1271 & 0.011 & 0.017 & 0.010 & 4.98 & 0.058 \\
\hline 12.01 & 1272 & 0.010 & 0.015 & 0.003 & 1.74 & 0.019 \\
\hline \multicolumn{7}{|c|}{ Chl max } \\
\hline 9.02 & 194 & 0.021 & 0.018 & 0.003 & 0.67 & 0.047 \\
\hline 10.02 & 276 & 0.042 & 0.028 & 0.003 & 1.30 & 0.090 \\
\hline 11.01 & 193 & 0.023 & 0.011 & 0.002 & 0.68 & 0.071 \\
\hline 12.01 & 69 & 0.018 & 0.015 & 0.003 & 0.47 & 0.079 \\
\hline
\end{tabular}


$0.125 \mathrm{~mol} \mathrm{C} \mathrm{Ein}{ }^{-1}$ ). These findings are consistent with other recent field studies (Bannister \& Weidemann 1984, Lewis et al. 1985, 1988, Kishino et al. 1986, Cleveland et al. 1989). For productivity models assuming a constant $\phi_{\text {max }}$ near the theoretical maximum, the present study would suggest they would overestimate rates of in situ photosynthesis by as much as 7 - to 10 -fold.

Variability in $\phi_{\max }$ can be related to several physical and biological parameters. Cleveland et al. (1989) suggested that $\phi_{\max }$ is proportional to the availability of inorganic nitrogen. Laboratory studies have demonstrated that nutrient stress can reduce reaction center activity without reducing light-harvesting capabilities (Kolber et al. 1988) and $\phi_{\max }$ decreases when nitrogen is limited (Welschmeyer \& Lorenzen 1981, Cleveland \& Perry 1987). Another factor which can affect $\phi_{\max }$ is light intensity. Over short time scales (hours to days) bright light (and/or UV light) can lead to photoinhibitory uncoupling of electron transport in photosynthetic membranes which leads to decrease in $\phi_{\max }$ (cf. Powles 1984). Over longer time scales (days to weeks) phytoplankton may adapt to bright light by increasing cellular concentrations of photoprotective pigments which can lower photoinhibiton stress (Demmig et al. 1987) but will result in a lower $\phi_{\max }$ (Bidigare et al. 1989). During the Watercolors ' 88 cruise, a significant portion of $a_{\mathrm{ph}}(\lambda) \mathrm{chl}^{-1}$ was attributable to photoprotective pigments (Prézelin et al. 1990, 1991) which had a large impact on the temporal and spatial contours of $\phi_{\max }$ (Prézelin et al. 1990, unpubl.). In situ $\phi_{\max }$ has been shown to be sensitive to temperature gradients (Tilzer et al. 1985) and diurnal periodicity in algal biology (cf. Prézelin 1991). For the data presented here no single environment factor could account for the spatial variability in $\phi_{\text {max }}$. We are pursuing analyses of the entire Watercolors ' 88 data base to assess to what extent the synergistic interaction of different environmental and endogenous variables regulate the quantum yield.

We have demonstrated that changes in algal community can be accompanied by significant shifts in the spectral properties of phytoplankton. For instance, photosynthetic action spectra were clearly sensitive to the presence of cyanobacteria. As in the recent study of Vernet et al. (1990), we found that the known presence of phycoerythrin in phytoplankton samples (Bidigare pers. comm.) could not be resolved in the $a_{p h}(\lambda)$ $\mathrm{chl}^{-1}$ spectra and it was the high quantum yield in the wavelengths associated with the phycobiliproteins which maintained photosynthetic rates. This is one example where taking into account the spectral dependence in $\phi(z)$ provided general information on community structure which could not be provided by nonspectral and empirical productivity models.

Similarly, the attenuation of $Q_{\text {par }}$ led to depth-dependent changes in the spectral signatures of light absorp- tion and radiation utilization efficiency. These spectral effects provided direct evidence of the importance of the accessory pigments in optimizing productivity deep in the euphotic zone. Studies have demostrated that chl is less effective as a light-harvesting pigment at greater optical depths (Smith et al. 1989b, Laws et al. 1990). Here, chl absorption accounted for only 20 to $40 \%$ of $A Q_{\mathrm{ph}}$ within chl max communities. A similar shift toward accessory pigmentation is seen in the spectral measurements of radiation utilization efficiency. Chl accounted for up to $80 \%$ of the utilized radiation in surface waters, compared to less than $40 \%$ at the chl max where light absorption by accessory pigments was most pronounced.

Comparisons of white light $\left[\alpha \mathrm{chl}^{-1}\right]$ and spectrally averaged $\left\{\bar{\alpha}\left(\Delta \lambda_{1}, z\right) \mathrm{chl}^{-1}\right\}$ light-limited slopes of photosynthesis indicated $\alpha \mathrm{chl}^{-1}$ values were routinely lower by 30 to $80 \%$ in surface waters and 75 to $85 \%$ at the chl max (Table 3). The difference between spectral and nonspectral $\alpha$ estimates was particularly pronounced for diatoms. White light estimates of $\phi_{\max }$ would suggest the diatoms had quantum yields very similar to the other chl max communities. However, estimates of spectrally averaged $\overline{\phi_{\max }}\left(\Delta \lambda_{i}, z\right)$ would suggest diatomdominated communities had quantum yields twice as high as picoplankton-dominated chl max communities (Table 3). In laboratory studies it has been demonstrated that the photosynthetic action spectra of phytoplankton match spectral growth irradiances (Bidigare et al. 1989, Schofield et al. 1990). Likewise, field studies have documented that $\alpha \mathrm{chl}^{-1}$ (Prézelin et al. 1989) and in situ production rates (Kiefer \& Strickland 1970 , Takahashi et al. 1989, Prézelin \& Glover 1991) are sensitive to the spectral output of the incubation lamps. These observations suggest that white light incubations give minimum estimates of quantum yield and that the lower values are likely related to the spectral bias of the tungsten light source used in photosynthetrons. This bias can be estimated by weighting $\alpha\left(\Delta \lambda_{1}, z\right) \mathrm{chl}^{-1}$ by the tungsten light field in the white light photosynthetrons $\left[Q_{d}\left(\Delta \lambda_{j}, \mathrm{P}-\mathrm{I}\right)\right]$ such that

$$
\bar{\alpha}=\frac{\sum Q_{d}\left(\Delta \lambda_{1}, \mathrm{P}-\mathrm{I}\right) \cdot \alpha\left(\Delta \lambda_{j} z\right) \mathrm{chl}^{-1}}{Q_{\mathrm{par}}(\mathrm{P}-\mathrm{I})}
$$

This should compensate for any spectral bias in the tungsten light field and $\overline{\alpha_{(P-l)}} \mathrm{chl}^{-1}$ should be directly comparable to $\alpha \mathrm{chl}^{-1}$ (Table 3). Despite these 'corrections' a significant discrepancy was still evident, especially for chl max measurements. Emerson enhancement effects inherent in a C-action spectra would increase this discrepancy further by up to $30 \%$ (Schofield et al. 1990). One testable hypothesis explaining the discrepancy is that pigmentation and photosynthetic activity are regulated by the presence 
of spectrally dependent photoreceptors (i.e. phytochrome and/or blue light receptors). The importance of photoreceptors in photosynthetic regulation in green algae and higher plants is well documented (cf. Senger 1987, Gilmartin et al. 1990). Phytoplankton may use the relative amount of red light (or the relative amount of red to blue light) as a cue that signals cells that the total irradiance is also increasing (as is true for any water column). Then the ever-present strong red light component of the tungsten light field in a white light photosynthetron would simulate bright light conditions and $\alpha \mathrm{chl}^{-1}$ values would be reduced on the time scale of hours as part of an overall photoadaptive strategy to increased irradiances (Richardson et al. 1983). This possible explanation of the regulation of the quantum yield can be tested by seeing whether or not increases in background red light can regulate spectral quantum yields.

The above observations are consistent with other studies which suggest optimal estimates of bio-optical parameters are those determined under light fields that best simulate in situ conditions (Prézelin et al. 1989, Laws et al. 1990). It appears advisable to at least filter red light out of white light incubators, although simulation of underwater spectral irradiance can be impractical at sea. The significance of these findings to productivity estimates depends upon the question asked. The overall impact of these differences on estimates of integrated water column productivity is small in water columns where the majority of phytoplankton activity is light-saturated (cf. Prézelin \& Glover 1991) As the discrepancy increases between white light and the in situ light field, the estimates of quantum yield, alpha, $I_{k}$ and thus the predictive capabilities of biooptical models deteriorate. As has been previously shown (Prézelin et al. 1989) this discrepancy will be greatest at any depth or location where $A Q_{p h}$ is dominated by green light absorption. Improvements in the spectral output of incubator lights used to define broadband biological parameters will improve our understanding of the photophysiology of phytoplankton. This combined with modeling efforts based on the wavelength-dependent properties of phytoplankton will improve the general ability to predict the temporal/spatial variability in ocean primary productivity.

The combined results of the present study support that view that all measures of in situ photosynthetic light utilization efficiencies (1) are temporally and spatially variable within a hydrographically defined water mass, (2) are spectrally dependent, and (3) exhibit a spectral plasticity that can be associated with changes in phytoplankton community composition and photophysiology. By linking spectral and nonspectral measurements in the same study, it has also been possible to illustrate pathways and limitations of different esti- mates of light utilization efficiency. Lastly, the study strengthens arguments that fully spectral models of phytoplankton productivity are conceptually more realistic and have more general applications than those that are not (Smith et al. 1989b), by providing insights into community composition as well as how phytoplankton utilize in-water spectral irradiance.

Acknowledgements. Research support was provided by the NSF grants OCE 8813728 (R.C.S.), OCE 8800099 (B.B.P.), OCE 8922935 (B.B.P.) and a NATO postdoctoral fellowship (P.M.S.). We gratefully acknowledge N. P. Boucher's assistance with all P-I measurements, H. A. Matlick's design and construction of the 'Prézelin' spectral photosynthetron, and Dr J. Endler's loan of a portable spectroradiometer We also thank Mr George Panagiotou (Cool Lux Inc.) for his generous donation of MiniCool Lamps and custom-designed housings. This Watercolors contribution No. 6 was also made possible by the assistance of R. R. Bidigare, D. K. Steinberg, E. Stephens, T Coley, D. Menzies, M. Ondrusek, A. Sloan, $\mathrm{K}$. Waters, and the crew of the RV 'Melville' Comments and suggestions by anonymous reviewers are acknowledged.

\section{LITERATURE CITED}

Baker, K. S., Smith, R. C, Bidigare, R. R., Prézelin, B. B., Lewis, M. R. (1990). A bio-optical model for the prediction of phytoplankton productivity during Fronts ' 85 and Watercolors '88. EOS 71: 147

Bannister, T T., Weidemann, A. D. (1984). The maximum quantum yield of phytoplankton photosynthesis in situ. $\mathrm{J}$ Plankton Res. 6: 275-294

Bidigare, R. R., Schofield, O., Prézelin B. B. (1989). Influence of zeaxanthin on quantum yield of photosynthesis of Synechococcus clone WH7803 (DC2). Mar. Ecol. Prog. Ser. 56 : $177-188$

Bidigare, R. R., Smith, R. C., Baker, K. S., Marra, J. (1987). Oceanic primary production estimates from measurements of spectra irradiance and pigment concentration. Biogeochem. Cycles 1. 171-186

Boucher, N. P., Schofield, O., Matlick, H. A., Prézelin, B. B., Smith, R. C., Bidigare, R. R. (1990). Patterns of primary productivity and photosynthesis-irradiance parameters across the Southern California Bight during the Watercolors '88 cruise. EOS 71. 146-147

Caceci, M. S., Cacheris, W. P. (1984). Fitting curves to data. Byte 9: $340-362$

Cleveland, J. S., Perry, M. J. (1987). Quantum yield, relative absorption and fluorescence in nitrogen-limited Chaetoceros gracilis. Mar. Biol. 94: 489-497

Cleveland, J. S., Perry, M. J., Kiefer, D. A., Talbot, M. C. (1989). Maximal quantum yield of photosynthesis in the northwestern Sargasso Sea. J. mar. Res. 47:869-886

Cote, B., Platt, T (1984). Utility of light-saturation curve as an operatonal model for quantifying the effects of environmental conditions on phytoplankton photosynthesis. Mar. Ecol. Prog. Ser 18:57-66

Demmig, B., Winter, K., Kruger, A., Czygan, F. (1987). Photoinhibition and zeaxanthin formation in intact leaves. Plant Physiol. 84: 218-224

Falkowski, P. G., Dubinsky, Z., Wyman, K. (1985). Growthirradiance relationships in phytoplankton. Limnol. Oceanogr. 30: 311-321 
Geider, R. J., Platt, T., Raven, J. A. \{1986\}. Size dependence of growth and photosynthesis in diatoms: a synthesis. Mar. Ecol. Prog. Ser. 30: 93-104

Gieskes, W. W. C., Kraay, G. W., Nontji, A., Setiapermana, D. Sutomo (1990). Monsoonal differences in primary production in the eastern Banda Sea (Indonesia). Neth. J. Sea Res. 25: 473-483

Gilmartin, P. M., Sarokin, L., Memelink, J., Chua, N. H. (1990). A review: molecular light switches for plant genes Plant Cell 2: 369-378

Glover, H. E., Prézelin, B. B., Campbell, L., Wyman, M. (1988) Pico- and ultra-plankton Sargasso sea communities: variability and comparative distributions of Synechococcus sp. and algae. Mar. Ecol. Prog. Ser. 49: 127-139

Iturriaga, R., Marra, J. (1988). Temporal and spatial variability of chroococcoid cyanobacteria Synechococcus spp. specific growth rates and their contribution to primary production in the Sargasso Sea. Mar. Ecol. Prog. Ser 44: 175-181

Kiefer, D., Mitchell, B. G. (1983). A simple steady state description of phytoplankton growth based on absorption cross-section and quantum efficiency. Limnol. Oceanogr. 28: $770-776$

Kiefer, D., Strickland, J. D. H. (1970). A comparative study of photosynthesis in seawater samples incubated under two types of light attenuator. Limnol. Oceanogr. 15: $408-412$

Kirk, J. T. O. (1983). Light and photosynthesis in aquatic ecosystems. Cambridge Univ. Press, Cambridge

Kishino, M., Okamiu, N., Takahashi, M., Ichimura, S. (1986). Light utilization efficiency and quantum yield of phytoplankton in a thermally stratified sea. Limnol. Oceanogr. 31: $557-566$

Kishino, M., Takahashi, M., Okamiu, N., Ichimura, S. (1985). Estimation of the spectral absorption coefficients of phytoplankton in the sea. Bull. mar. Sci. 37: 634-642

Kolber, Z. J., Zehr, J., Falkowski, P. (1988). Effects of growth irradiance and nitrogen limitation on photosynthetic energy conversion in photosystem Il. Plant Physiol. 88: $246-253$

Laws, E. A., Bannister, T. T. (1980). Nutrient-and light-limited growth of Thalassiosira fluviatilis in continuous culture, with implications for phytoplankton growth in the ocean. Limnol. Oceanogr. 25: 457-473

Laws, E. A., DiTuillo, G. R., Carder, K. L., Betzer, P. R., Hawes, S. (1990). Primary production in the deep blue sea. Deep Sea Res. 37: 715-730

Laws, E. A., DiTuillo, G. R., Redalje, D. G. (1987). High phytoplankton growth and production rates in the North Pacific subtropical gyre Limnol. Oceanogr. 32: 905-918

Lewis, M. R., Ulloa, O., Platt, T (1988). Photosynthetic action, absorption and quantum yield spectra tor a natural population of Oscillatoria in the North Atlantic. Limnol. Oceanogr. 33: $92-99$

Lewis, M. R., Warnock, R. E., Platt, T (1985). Measuring photosynthetic action spectra of natural phytoplankton populations. J. Phycol. 21: 310-315

MacCaull, W. A., Platt, T (1977). Diel variations in the photosynthetic parameters of coastal marine phytoplankton. Limnol. Oceanogr. 22: 723-731

Morel, A. (1978). Available, useable, stored radiant energy in relation to marıne photosynthesis. Deep Sea Res. 25: 673-688

Morel, A., Lazzara, L., Gostan, J. (1987). Growth rate and quantum yeld time response for a diatorn to changing irradiances (energy and color). Limnol Oceanogr. 32: $1066-1.084$
Morris, I. (1980). The physiological ecology of phytoplankton Blackwell Sci. Publ., Berkeley

Nelson, N. B., Prézelin, B. B. (1990). Chromatic light effects and physiological modeling of absorption properties of Heterocapsa pygmaea, aka Glenodinium sp. Mar. Ecol. Prog. Ser. 63; 37-46

Platt, T. (1986). Primary production of ocean water column as a function of surface light intensity: algorithms for remote sensing. Deep Sea Res. 33: 149-163

Platt, T., Gallegos, C. L. (1980). Modeling primary productivity. In Falkowski, P. (ed.) Primary production in the sea. Plenum Press, New York, p. 339-362

Platt, T., Jassby, A. D. (1976). The relationship between photosynthesis and light for natural assemblages of coastal Maine phytoplankton. J. Phycol. 12: 421-430

Platt, T., Sathyendranath, S. (1988). Oceanic primary production: estimation by remote sensing at local and regional scales. Science $241 \quad 1613-1620$

Powles, S. B. (1984). Photoinhibition of photosynthesis induced by visible light. In: Briggs, W. R., Jones, R. L., Walbot, V. (eds.) A. Rev. Pl. Physiol. 35: 15-44

Prézelin, B. B. (1981). Light reactions in photosynthesis. In Platt, T (ed.) Physiological bases of phytoplankton ecology. Can. Bull. Fish. Aquat. Sci. 210: 1-43

Prézelin, B. B. (1991). Diel periodicity in phytoplankton productivity. Hydrobiologia (in press)

Prézelin, B. B., Bidigare, R. R., Matlıck, H. A., Ver Hoven, B. (1987). Diurnal patterns of size-fractionated primary productivity across a coastal front. Mar. Biol. 96: 563-574

Prézelin, B. B., Boczar, B. A. (1986). Molecular bases of cell absorption and fluorescence in phytoplankton: potential applications to studies in optical oceanography. Prog. Phycol. Res. 4: 350-464

Prézelin, B. B., Glover, H. E., Ver Hoven, B. M., Steinberg, D., Matlick, H. A., Schofjeld, O., Nelson, N. B., Wyman, M., Campbell, L. (1989). Blue-green light effects on light-limited rates of photosynthesis: relationship to pigmentation and productivity estimates for Synechococcus populations from the Sargasso Sea. Mar. Ecol. Prog. Ser. 54: 121-136

Prézelin, B. B., Glover, H. E. (1991). Variability in time/space estimates of phytoplankton, biomass and productivity in the Sargasso Sea. J. Plankton Res. 13S: 45-67

Prézelin, B. B., Putt, M., Glover, H. E. (1986). Diurnal patterns in photosynthetic capacity and depth-dependent photosynthesis-irradiance relationships in Synechococcus spp and larger phytoplankton in three water masses in the northwest Atlantic Ocean. Mar. Biol. 91. 205-217

Prézelin, B. B., Smith, R. C., Bidigare, R. R. (1990). Photosynthetic quantum yield and light utilization efficiency in the Southern Calıfornia Bight. EOS 71. 146

Prézelin, B. B., Tilzer, M. M., Schofield, O., Haese, C. (1991). The control oi the production process of phytoplankton by the physical structure of the aquatic environment with special reference to its optical properties. Aquat. Sci. 53: $136-186$

Rıchardson, K., Beardall, J., Raven, J. A. (1.983). Adaptation of unicellular algae to irradiance: an analysis of strategies. New Phytol. 93: 157-191

Sakshaug, E., Andresen, K., Kiefer, D. A. (1989). A steady state description of growth and light absorption in the marine planktonic diatom Skeletonema costatum. Limnol. Oceanogr. 34: 198-204

Sakshaug, E., Johnsen, G., Andresen, K., Vernet, M. (1991). Modeling of light-dependent algal photosynthesis and growth: experiments with the Barent Sea diatoms Thalassiosira nordenskioeldij and Chaetoceros furcellatus. Deep Sea Res. 38: 415-430 
Sathyendranath, S. Lazzara, L., Prieur, L. (1987). Variations in the spectral values of specific absorption of phytoplankton. Limnol. Oceanogr 32: 403-415

Sathyendranath, S., Platt, T., Caverhill, C. M., Warnock, R. E., Lewis, M. R. (1989). Remote sensing of oceanic primary production: computations using a spectral model. Deep Sea Res. 36: 431-453

Schofield, O., Bidigare R. R., Prézelin, B. B. (1990). Spectral photosynthesis, quantum yield and bluegreen light enhancement of productivity rates in the diatom Chaetoceros gracile and the prymnesiophyte Emiliana huxleyi. Mar. Ecol. Prog. Ser. 64: 175-186

Senger, H. (1987). Blue light responses: phenomena and occurence in plants and microorganisms, Vol. II. CRC Press, Florida

Shuter, B. (1979). A model of physiological adaptation in unicellular algae. J, theor. Biol. 78: 519-552

Sloan, A., Bidigare, R. R. (1990). Spatial variations and temporal evolution of algal pigment distributions in the Southern California Bight. EOS: 146

Smith, R. C., Baker, K. S. (1984). The analysis of ocean optical data. In: Ocean Optics 7., proc. SPIE. 489: 119-126

Smith, R. C., Bidigare, R. R., Prézelin, B. B., Baker, K. S., Brooks, J. M. (1987). Optical characterization of primary productivity across a coastal front. Mar. Biol. 96: 575-591

Smith, R. C., Booth, C. R., Starr, J. (1984). Oceanographic biooptical profiling system. Appl. Optics 23: 2791-2797

Smith, R. C., Marra, J., Perry, M. J., Baker, K. S., Swift, E., Buskey, E., Kiefer, D. A. (1989a). Estimation of a photon

This article was submitted to the editor budget for the upper ocean in the Sargasso Sea. Limnol Oceanogr. 34: 1673-1693

Smith, R. C., Prézelin, B. B., Bidigare, R. R., Baker, K. S (1989b). Bio-optical modeling of photosynthetic production. Limnol. Oceanogr. 34: 1526-1546

Smith, R. C., Prézelin, B. B., Bidıgare, R. R., Lewis, M. R., Baker, K. S. (1990). Bio-optical modeling of phytoplankton productivity in the Southern California Bight during times of variable upwelling. EOS: 121

Stewart, W D. F. (1974). Algal physiology and biochemistry. Univ. California Press, Berkeley

Takahashi. M., Ichimura, S., Kishino, M., Okami, N. (1989). Shade and chromatic adaptation of phytoplankton photosynthesis in a thermally stratified sea. Mar Biol. 100: 401-409

Tilzer, M. M., Bodungen, B., Smetacek, V. (1985). Lightdependence of phytoplankton photosynthesis in the Antarctic ocean: implications for regulating productivity. In Siegfried, W. R., Condy, P. R., Laws, R. M. (eds.) Antarctic nutrient cycles and food webs. Springer-Verlag, Berlin, p. $60-69$

Vernet, M., Mitchell, B. G., Holm-Hansen, O. (1990). Adaptation of Synechococcus in situ determined by variability in intracellular phycoerythrin-543 at a coastal station off the Southern California coast, USA. Mar. Ecol. Prog. Ser. 63: 9-16

Welschmeyer, N. A., Lorenzen, C. J. (1981). Chlorophyllspecific photosynthesis and quantum efficiency at subsaturating light intensities. J. Phycol. 17: 283-293

Manuscript first received: April 10, 1991

Revised version accepted. November 6, 1991 